\title{
EPISTEMICIDE: THE ROMAN CASE ${ }^{1}$
}

Dan-el Padilla Peralta*

Recebido em: 11/06/2020 Aprovado em: 01/07/2020
*Associate Professor of Classics, Princeton University. dpadilla@princeton.edu

\begin{abstract}
The desire to recover and preserve the antiquity that in some circles is designated as "classical" is rooted in the conviction that knowledge of that antiquity is a good. But does (or should) awareness of the epistemicides that define Greco-Roman antiquity modify the texture of that desire? Relying on the definition of epistemicide proposed by the postcolonial theorist Boaventura de Sousa Santos, this article argues that the Roman Republic and Empire engineered a staggering loss of epistemic diversity throughout the ancient Mediterranean, traceable along multiple vectors - from mass enslavement to ecological upheaval. It concludes with a summons to come to terms with the scope of ancient Rome's epistemicide, and to embrace the epistemological and ethical recalibration needed to write its history.
\end{abstract}

KEYWORDS: epistemicide; Roman Republic and Empire; postcolonial; indigeneity; slavery; Mediterranean; extractivism; ecology.

\section{EPISTEMICÍDIO: O CASO ROMANO}

RESUMO: O desejo de recuperar e preservar a antiguidade que em alguns círculos se denomina "clássica" está enraizado na convicção de que o conhecimento dessa antiguidade é um bem. Mas a consciência dos epistemicídios que definem a antiguidade greco-romana modifica (ou deveria modificar) a textura desse desejo? Baseando-se na definição de epistemicídio proposta pelo teórico pós-colonial Boaventura de Sousa Santos, este artigo defende que a República e o Império romanos

\footnotetext{
${ }^{1}$ Versions of this paper were delivered as a keynote at the XXII Congresso da Sociedade Brasileira de Estudos Clássicos and as lectures at the University of San Francisco, the University of Texas at San Antonio, Harvard University, the University of Virginia, and the University of Toronto. My thanks to all these audiences, and especially my hosts in Brazil.
} 
engendraram uma perda impressionante de diversidade epistêmica em todo o Mediterrâneo antigo, rastreável ao longo de múltiplos vetores - da escravidão em massa ao desastre ecológico. Conclui-se com uma convocação para que haja reconhecimento sobre o escopo do epistemicídio da Roma antiga, abraçando a recalibração epistemológica e ética necessária para escrever sua história.

PALAVRAS-CHAVE: epistemicídio; República e Império Romano; pós-colonial; indigenismo; escravização; Mediterrâneo, extrativismo; ecologia.

Hoc tunc Vei fuere. Nunc fuisse quis meminit? Quae reliquiae? Quod vestigium?

That, then, was Veii. Who remembers its existence now? What are the remnants? What are the traces?

Florus 1.6.11

$\mathrm{I}$ $\mathrm{n}$ a fragment of his Miscellany Banquets that survives only by the slender thread of quotation in Athenaeus, the fourth-century BCE philosopher Aristoxenus of Tarentum reported the following about the Greeks of Paestum: ${ }^{2}$

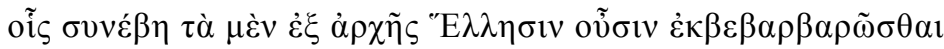

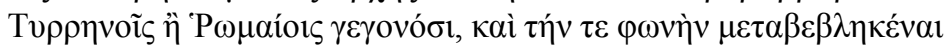

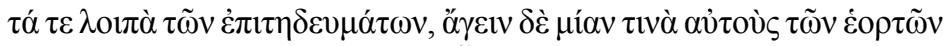

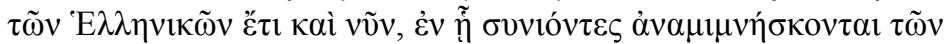

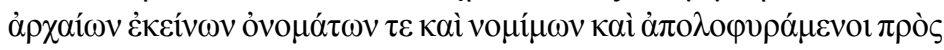

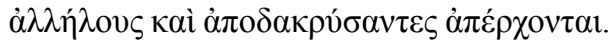

For it fell to them, though they were Greeks at first, to have thoroughly barbarized, becoming Etruscans or Romans, and to have changed their language, and all the rest of their ways of life, except for one of the Greek festivals they do hold even to the present day, in which they come together and recollect all their ancient names and customs, and grieve before one another. Once they have wept for them, they depart.

Aristoxenus had a front-row seat for those Oscan migrations that, beginning in the late fifth century, altered the fabric and rhythm of Greek life in peninsular Magna Graecia. These migrations opened the door to other bellicose central Italians who in due course asserted control over Paestum, culminating in the Roman foundation of a colony there some decades after Aristoxenus' death. This historical background, and even the historical content of Aristoxenus' remark, matters less for my immediate aims than his premise: that a community facing overwhelming military and political pressure could barbarize to the point

\footnotetext{
${ }^{2}$ Aristoxenus fr. 124 Wehrli $=$ Athenaeus Deipnosophistae 14.632.
} 
of losing its culture. ${ }^{3}$ Among modern treatments of this passage's project, Emma Dench's contextualization of this premise within "arrival of the barbarians" narratives can be read with much profit. ${ }^{4}$ It is notable that the Greek loss of culture at Paestum in the era of Oscan (and Tyrrhenian) ascendancy was not figured by Aristoxenus as total: Poseidonians managed to stage one annual reminder of what was lost, and to mourn the scale and scope of that loss. But the success of Greek authors such as Aristoxenus in putting down foundations for tropes of Greek cultural loss should not blind us to one manifest irony of this passage, namely that those western Greeks who bewailed the loss of their culture were in many cases descended from colonists whose collisions with indigenous cultures did not always end favorably for the latter.

A related and arguably greater irony is that Aristoxenus was writing at a time when non-Greek-speaking or Greek-identifying communities up and down the Italian peninsula (and beyond) were capitalizing on the potential of philhellenism, whether in the course of internal political differentiation or through peer-polity conflict. ${ }^{5}$ Donning the mask of philhellenism, communities charted a course for their own survival in an anarchic Mediterranean world. But adaption of philhellenism for the sake of such survival came at a price, even for those who lived to tell the tale "on the middle ground" and thereby "created new valuables, new cultural goods". ${ }^{6}$ The price of the ticket was loss. This article outlines and evaluates a variety of loss so total that the effort to describe it will strike some readers as a hopelessly presumptuous project: the obliteration of epistemic diversity, a direct consequence of those processes of Mediterranean-wide imperial consolidation and expansion that were in full swing by the time Aristoxenus wrote.

While anti-imperialist critiques remain on the critical radar of many historians though perhaps not nearly to the extent that they used to be in the era of decolonization - these critiques have been met in recent years with the dusted-off argument that, on the whole and in the long term, imperial violence ultimately generated many more benefits than harms. I say "dusted-off" because this argument, formerly a staple of justifications for Roman imperial expansion and by extension for those empires modeled along or selfconsciously dialoguing with the Roman Empire (e.g. the British Empire), was subjected to withering criticism for a lengthy stretch of the $20^{\text {th }}$ century, only then to be rehabilitated and dragged back out into the open. Relying on a rhetoric whose origins are themselves traceable to premodern imperial systems throughout the world, proponents of the empire-is-good gospel have moved from simply asserting the civilizing force of imperial domination over barbarism to adopting a language and an evidentiary scheme more in tune with late $20^{\text {th }}$ and $21^{\text {st }}$-century Global Northern sensitivities: over time, and despite horrifically destructive episodes of mass state-coordinated violence, empires monopolized and centralized power

\footnotetext{
${ }^{3}$ For a comparison-case note Liv. 37.54 on Massalia, with Dietler (2010, p. 109-11) for critique.

${ }^{4}$ Dench $(1995$, p. $50-3)$.

${ }^{5}$ Gallini (1973) is fundamental; cf. Dench (2003, p. 298-304) on the malleability of philhellenism.

${ }^{6}$ I quote from Woolf (2011, p. 28).
} 
to the benefit of those under their control; their lives became safer, more secure, and often even better resourced as a result.

My visceral aversion to this line of reasoning is grounded in my own personhood, as a descendant of West Africans who were trafficked in the trans-Atlantic slave trade; in the Spanish-speaking colonizers of the Western Hemisphere who first set that traffic into motion; and in the indigenous Caribbean communities whose demographic depletion at the hands of these colonizers motivated the turn to new sources of exploitable human labor. At the core of my objection is the recognition that imperial violence does not merely manifest in the destruction of human life, but in the obliteration of forms of knowing as well: epistemicide. The postcolonial theorist Boaventura de Sousa Santos has defined this species of obliteration as follows:

Colonial domination involves the deliberate destruction of other cultures. The destruction of knowledge (besides the genocide of indigenous people) is what I call epistemicide: the destruction of the knowledge and cultures of these populations, of their memories and ancestral links and their manner of relating to others and to nature.

In concert with other postcolonial critics of $21^{\text {st }}$ century global capitalism, Santos has exhorted his readers to build communities of knowledge and knowledge production that, consciously and methodically departing from the learning styles and epistemic habits of the Euro-American West and Global North, embrace "epistemologies of the Global South," in partial rectification of the historic and ongoing epistemicide to which communities in the Global South and marginalized peoples in the Global North have been subjected. ${ }^{8}$ Such a rectification of loss can only be partial: in some contexts, epistemicide renders many distinctive forms of knowledge-holding and bearing irrecoverably extinct, thereby entrenching the varieties of epistemic injustice that have been studied by philosophers such as Miranda Fricker and José Medina; in others, epistemicide hitches a ride with the extraction and commodification of indigenous knowledges, according to the logic of what Laurelyn Whitt has termed biocolonialism. By confronting these forms of epistemic violence, historians can more empathetically engage with power's role in the production of history.

Taking to heart the insights of these and other postcolonial theorists, ${ }^{10}$ early modern and modern historians of slavery have repeatedly and productively probed loss as a site for inquiry and reflexivity. Anthropologists and political scientists have also applied themselves

\footnotetext{
${ }^{7}$ Santos (2016, p. 18), summarizing Santos (2014).

${ }^{8}$ Santos (2018). For criticism of Santos's own epistemological blind-spots note Connell (2014).

${ }^{9}$ Fricker (2007); Medina (2013); Whitt (2009). See Trouillot (1995) for the relationship of power to the constitution of historical archives; cf. Hartman (2008) on the recovery of the "unspeakable and the unknown."

${ }^{10}$ Crucial for shifting the terms of debate among historians: Chakrabarty (2000); Mignolo (2002).
} 
to the theme in recent years. ${ }^{11}$ By contrast, with rare exceptions ancient historians have been less inclined to proceed down this route, even as the resources and incentives for doing so continue to accumulate. In a preliminary and necessarily incomplete attempt at redress, this article proposes to apply Boaventura de Sousa Santos' framework for epistemicide to one premodern imperial system: the imperial Roman Republic of the last three and a half centuries BCE. ${ }^{12}$

Staked to a head start among competitor central Italian city-states, the Roman Republic expanded dramatically, first by liquidating opposition in the Italian peninsula and then by expanding west and east - along the way dealing death blows to the Carthaginian Empire, multiple Hellenistic kingdoms and city-states, and numerous decentralized tribal confederations and non-urbanized populations. This expansion was accompanied by paroxysms of mayhem that blotted out the lives and cultures of communities all around the Middle Sea. Even though Romans marketed themselves as the beneficiaries of a robust alliance system, partnerships were not forged between equals: the threat of drastic and everlasting devastation always loomed, with $146 \mathrm{BCE}$ - the year that the Roman state destroyed both Carthage and Corinth - representing a watershed in the imperial Republic's willingness not only to defeat its adversaries but also to spectacularize its commitment to their complete destruction. ${ }^{13}$ That there were in some cases survivors of the conquests who went on to be incorporated or assimilated into Roman society does not blunt the most obvious point, which is that many millions died. According to the tabulations of their mastermind, Julius Caesar's first-century campaigns in Gaul resulted in the slaughter of over one million people, and this only for a ten-year period of military activity. By his own calculations, or those of his delegate body-counters, Caesar's partner-turned-adversary Pompey could boast of the defeat, dispersal, killing, or surrender of $12,183,000$ people. ${ }^{14}$ Whatever one makes of these literary reports, newly published archaeological evidence from the Germanic frontier zone has supplied fresh corroboration of the imperial expansion's rapacity. ${ }^{15}$

Whether the ancient Mediterranean has a place in the history of genocide remains a subject of lively and occasionally testy debate. ${ }^{16}$ This paper does not seek to deliver an

\footnotetext{
${ }^{11}$ Political theory: see e.g. Dumm (2000), taking his cue from Sheldon Wolin. Anthropology: Pollock (2016) on suffering, making use of Adorno's negative dialectics (on which more below).

${ }^{12}$ All dates in this article are BCE.

${ }^{13}$ The signaling force of these city sackings: Purcell (2003).

${ }^{14}$ Caesar's boast: Plut. Caes. 15.3 and App. Celt. fr. 1 with Osgood (2009, p. 332). Pompey's figures: Pliny NH 7.97, quoting from the dedication of spoils at the temple of Minerva in Rome. Skepticism about figures of this sort has made for good sport ever since the Scottish Enlightenment (see David Hume's "Of the populousness of ancient nations"); but even if Julius Caesar or Pompey exaggerated to the tune of a full order of magnitude the losses would be substantial.

${ }^{15}$ Roymans (2019).

${ }^{16}$ Barrandon (2018, ch. 9) is a lucid survey of the main positions; I do not agree with some of her conclusions. Dyson, 1985 on Roman frontiers concedes that the "wars with the Gauls in Italy came closest to genocide" but then claims that Romans understood their wars in the west "much as the
} 
authoritative verdict on the extent to which Romans pursued the targeting and extermination of specific ethnic groups in accordance with an explicitly formulated genocidal agenda. What it will contend is that Roman imperialism was responsible for the extermination of contingent, context-dependent, and multi-generational ways of knowing that were tied directly and inalienably to the people and places responsible for their transmission and evolution. Unquestionably, some ways of knowing did endure, and not only in areas where the penetration of Roman state power was only minimally felt; for example, the "extreme traditionalism" of Mediterranean fishing practices reflects one species of epistemic continuity across the chasm of imperial violence. ${ }^{17}$ But for many other ways of knowing, there was precious little chance of outlasting the purge if these had not already been redacted into a literary form with which the Hellenizing Romans had some familiarity. ${ }^{18}$

I offer one example as an illustrative teaser. In the aftermath of the Third Punic War, the decision of the Roman Senate to entrust a member of their ranks, Decimus Junius Silanus, with the leadership of a commission charged with translating the Carthaginian Mago's agricultural treatise has been variously read as an indication of Roman pragmatic hardheadedness or as a reflection of the limits of Carthage's own participation in the literature-producing exploits of the Hellenistic Mediterranean. ${ }^{19}$ But this episode also exposes the fragility of culturally specific knowledge in the face of empire's rampaging force: if not already legible to and therefore instrumentalizable by the agents of empire, the odds of that knowledge leaping across the chasm of genocide and destruction swiftly declined from slim to none. Denis Feeney has argued that the creation of a Roman literature so intimately versed in and responsive to Greek literature in the last several centuries BCE is a distinctive geopolitical event, with few parallels in other times and spaces of imperial contact. ${ }^{20}$ However, what makes the Romans seem so distinctive may very well be an epiphenomenon of their appetite for dismembering other knowledge practices and systems. Pliny the Elder's statement that the Senate authorized the translation of Mago's text at the same time that it scattered the contents of Carthage's libraries to the kings of Africa (cum regulis Africae bibliothecas donaret)

British looked on the combats along the northwestern frontier of India" (p. 273-5) - without any recognition of the scale of the latter. For other studies of genocide in antiquity see n. 38 .

${ }^{17}$ I quote from the introduction to Marzano (2013), who makes a powerful case for the persistence of "an assemblage of experiential knowledge [about fishing] accumulated through time and passed down to subsequent generations" (p. 1). But some of the evidence presented in her book points towards epistemic disruption; see Part III of this article.

${ }^{18}$ Or if these knowledges did not leave textual remnants that could be deciphered many centuries later: cf. Geller (1997) on ancient cuneiform script and Babylonian culture.

${ }^{19}$ Pliny NH 18.5.22-3; on this treatise's usefulness to Roman elites see Fentress (2013, p. 170-2). Note also Varr. RR 1.1.10, with Lewis (2018, ch. 13) on Carthaginian agriculture's reliance on large-scale slavery. Awareness of Punic literary culture among Romans: Wallace-Hadrill (2006, p. 83-4).

${ }^{20}$ Feeney (2016). 
leave little doubt that not just intellectual appropriation but despoliation and fragmentation form part of the epistemicidal story. ${ }^{21}$

Pliny's reference to bibliothecae makes tangible another feature of the multidimensional epistemic leveling of concern to this article: imperialism's attachment to the warehousing of knowledge, in the form of libraries and museums. ${ }^{22} \mathrm{My}$ approach to epistemicide crossfertilizes a strand of scholarship on the Roman expansion that was far more critical (and in some cases even mournful) of Rome's pulverizing disruption of local Italic cultures with the work of Edward Said and his many postcolonial interlocutors. ${ }^{23}$ It is customary in a postSaid vein to characterize empires as knowledge- and information-aggregative enterprises. Roman historians have lately turned their gaze to those sites and processes within the city of Rome itself that were conduits for the publicization and dissemination of imperially extracted knowledge, from the "moving museum" of the Roman triumph to the botanical imperialism of Vespasian's gardens. ${ }^{24}$ The darker side of the role of libraries and museums in the amassing and warehousing of knowledge is not only the deracination of these knowledges from the environments in which they had previously been incubated, but the legitimation of the impression that only what is in those warehouses deserves to be known. For this reason alone, ancient and modern libraries and museums have been (and, barring reparative and emancipatory interventions, will continue to be) thoroughly implicated in the processes of imperial epistemicide. ${ }^{25}$

At this stage, we should spell out what these processes were. The first and most obvious one is extensive genocide itself, and the subjugation of those who did manage to survive into the social death of slavery. The second is ecological devastation, nowhere more conspicuous than in the steady deforestation of swathes of the Italian peninsula and the Mediterranean basin, as population growth and urbanization combined with the intensification of military conflicts to create escalating demands for natural resources such as wood, charcoal, and stone. The Roman state actively engineered local ecologies for profit- and rent-extractive ends, ${ }^{26}$ with calamitous consequences for the knowledges that had previously been attached to these ecologies. The third is the commercial transformation

\footnotetext{
${ }^{21}$ Further on the handling on libraries by Roman forces cf. Plut. Aem. 28.6 (L. Aemilius Paullus' retention of Perseus' royal library); Plut. Sull. 26 and Strabo 13.1.54 (Sulla's importation of Apellicon's library); Pliny NH 25.3.6 and Isid. Etym. 6.5.1 (Pompey's acquisition of Mithridates' collection of botanical texts; Lucullus' raiding of Mithridates' library). The traffic in texts under the eyes of empire: Myers (2017).

${ }^{22}$ Usefully on libraries and the compilation of ethnographic knowledge: Woolf (2011, p. 24-5).

${ }^{23}$ Scholarship on the Italian peninsula's loss of cultural diversity in the era of the Roman expansion: Terrenato (2019, p. 16-7) on Étienne de Condillac, Giuseppe Galanti, Giuseppe Micali, and Johann Herder.

${ }^{24}$ On the latter see Pollard (2009). Explicit in its recourse to Said: Wallace-Hadrill (2008, p. 213-5).

${ }^{25} \mathrm{~A}$ critical reading of three contemporary museum exhibits with discussion of what such interventions might entail: Bosak-Schroeder (2020, ch. 6).

${ }^{26}$ Pithy exposition: Wilson (2012). On stone in particular see Russell (2017).
} 
of the Mediterranean world, either immediately preceding (and in some cases cited as justification for) Roman military intervention or as a secondary and codependent consequence of those state-formation and economic networks that bound communities in increasingly tightening circuits of dependency on specific goods, ranging from gold and silver coinage to the intoxicating drug of wine. ${ }^{27}$ The fourth is the loss of linguistic diversity, a multicentury process that left virtually no region of the greater Mediterranean untouched but was especially pronounced in the Roman West. ${ }^{28}$ The fifth and final process is the fitful but ultimately unrelenting encroachment of Roman religious and legal systems over other parts of the Mediterranean, resulting in the emergence of a new rubric of legal sovereignty. ${ }^{29}$

Set in motion by Republican imperialism and consummated in the High Empire, the processes were interdependent and synergistic, as research into the compounding amplification of the first and third has confirmed in recent years: those Gallic chieftains who trafficked enslaved persons for Italian wine were hardly independent actors on the borderlands of the Roman expansion, and the negotiatores who sold them that wine did not have to be active "agents of a policy of cultural imperialism" for their routines to have lasting epistemic consequences..$^{30}$ However, as a comprehensive account of these processes in their synergistic glory would require not one but several monographs, this article will train its sights primarily on mass enslavement and ecological change. Also with an eye to brevity, this article will exclude several related topics from further consideration. The epistemicide under examination below is not reducible to or isomorphic with the vanished libraries of the ancient Mediterranean, despite my gesture to this dynamic earlier. ${ }^{31}$ And notwithstanding this article's opening gambit, there will be no take-up of those Greek or Roman authors who could be said to have theorized epistemicide avant la lettre, either in the form of philosophical treatises on human destruction or in the form of anti-Roman and/ or anti-imperial polemics. ${ }^{32}$ From Cato the Elder's Origines to Vergil's Aeneid, Latin literature

\footnotetext{
${ }^{27}$ Wine and commodity circuits in Gaul: Dietler (2010, ch. 7) (and see n. 30). Wine's role as a trigger for military conflict remains understudied, but note Andreas (2019). For economic integration in the final few centuries BCE see Roselaar (2019, chs. 3-4); on monetization, Howgego (2013).

${ }^{28}$ Dietler (2010, p. 8) on "the gradual extinction of indigenous languages" in the Roman West; cf. Clackson and Horrocks $(2007$, p. 88) on the characteristics of those languages that did survive.

${ }^{29}$ Roman law's imperial metastasis, through analogy and fiction: Ando (2019).

${ }^{30}$ I am quoting Daubner (2019, p. 150), whose stance on negotiatores in the late-republican Balkans strikes me as naïve. The wine-enslavement nexus: Diod. 5.26.3 on Gaul; on analogous patterns at the head of the Adriatic and in the Black Sea see Strabo 5.1.8 and 2.2.4 with Fentress (2011, p. 65); cf. Crawford (1977) on hoards of Republican denarii in Romania.

31 "The vanished library" of Alexandria: Canfora (1989).

${ }^{32}$ The causes of human destruction: Dicaearchus of Messana's de interitu bominum (Cic. Off. 2.5.16); for conflicting interpretations of this text's relevance to genocide studies see Barrandon (2018, p. 314-5). Anti-Roman polemics, either placed in the mouths of non-Romans by Roman writers or penned by non-Romans themselves: Sallust's Mithridates (Hist. 4.69 Maurenbrecher), Caesar's Critognatus (BG 7.77, to be read with Riggsby, 2006, ch. 4), and Tacitus' Calgacus (Agr. 30-32) fall in the first category;
} 
offers a variety of unsettling meditations on epistemicide; but a canvassing of these texts will be deferred for now. ${ }^{33}$

This paper intentionally avoids wading into debates about Romanization. Even in the most nimble hands, studies that work through or around rubrics of Romanization (or Hellenization) privilege in an almost jauntily upbeat way the subaltern's accumulation of cultural identities ${ }^{34}$ downplaying the extent to which expansionist violence uprooted and displaced local knowledges. In counterpoint, this paper will focus mainly on elucidating, in the spirit of Theodor Adorno's negative dialectic, those ghostly remainders of suffering and loss that otherwise elude full representation and characterization in historically positivist accounts..$^{35}$ Finally it should be noted that, while this project is broadly sympathetic to recent pleas to embrace the "ontological turn" in the study of Greco-Roman antiquity, ${ }^{36}$ it resists heeding them. A rigorous execution of the ontological turn in ancient historical studies would at a minimum entail grappling with the pluriverse of ways of knowing that were menaced, and in many cases hounded into extinction, by empire; but I will not initiate that undertaking below.

\section{Militarism, GENOCIDE, AND SLAVERY}

O Sheikh Hunter, I cannot write my life, I have forgotten much of my talk as well as the talk of the Maghreb. O my brothers, do not blame me.

Omar Ibn Said, The Life of Omar Ibn Said (1831) (2011, p. 59).

Few literary testimonies bang home the purposeful violence of the Roman military machine with the clarity of the Greek historian Polybius' description of New Carthage's sacking at Roman hands during the Second Punic War:

in the second, Metrodorus of Scepsis and possibly Timagenes of Alexandria, on whom see Yarrow (2006, ch. 6) and Whitmarsh (2018); note also Ballesteros Pastor (2009) on Justin Epit. 28.2.

33 Jefferson (2012) on the multiculturalism of the Origines overlooks the extent to which Cato's archaeologies presume, and in some cases directly acknowledge, pervasive cultural death: see e.g. FRHist F34b on the Ligurians. Vergil: Aen. 12.837 for Jupiter's promise to make out of diverse adversaries omnis uno ore Latinos; Wimperis (2020) on "Italian solidarity." Generally on the epic's ethnographic project: Ando (2002, p. 138-40); Barchiesi (2008); De Santis and Ames (2011).

${ }^{34}$ Examples: Wallace-Hadrill (2008, chs. 1 and 3); Roselaar (2019, ch. 1.4.-5).

35 Adorno ([1966] 1990), with Bennett (2010, ch. 1) on Adorno's materialism. The relevance of Adorno's orientation towards suffering and loss to archaeologists: Pollock (2016).

${ }^{36}$ Provocatively: Anderson (2018). 


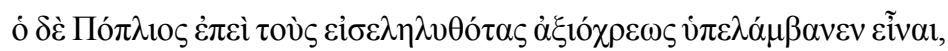

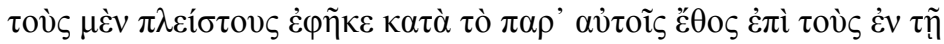

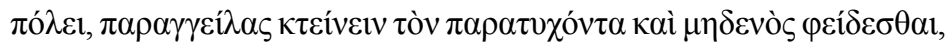

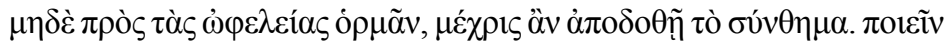

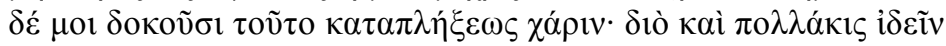

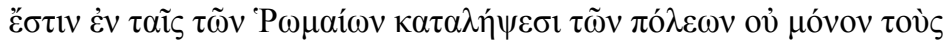

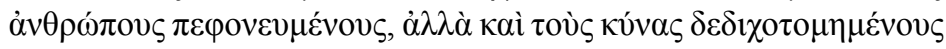

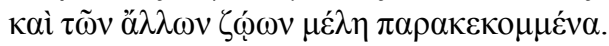

Publius [Cornelius Scipio], when he thought that enough troops had entered the town, sent most of them, as is the custom among the Romans, against those in the city, ordering them to kill whoever they met and to spare no one, and not to begin plundering until the signal had been given. They do this, it seems to me, in order to inspire terror. For this reason, one can often see in the cities sacked by the Romans not only humans slaughtered, but even dogs cut in two and the severed limbs of other animals. ${ }^{37}$

I cite Polybius here not with an eye to commenting on his regard for Roman violence in its most uncompromisingly genocidal manifestation, ${ }^{38}$ or in the interests of holding forth on the substantiation of this and similar narratives through the spectacularly grim findings of battlefield archaeology. ${ }^{39}$ Rather, my concern is with the militarized process whose full ramifications are only partially registered in the historiography of the conquest: mass enslavement. Those adversaries of Rome who were not slaughtered on the battlefield or in the immediate aftermath of military victory survived only to be enslaved.

Throughout the period under discussion in this article, the treatment of captives was differential in nature, with elites and previously free people of moderate means able to bargain (or ransom) their way to a better fate than those non-elites and previously enslaved who were funneled back to Rome as public slaves or trafficked on the market. This pattern is well attested for other premodern and early modern slaving regimes. ${ }^{40}$ In Roman culture, the durability of the link between militarized violence and slavery is discernible in the Roman jurisprudential tradition's etymologizing of servi as those who have been servati, i.e. "saved" from death. By one conservative estimate, from the first decade of the third century BCE to its epoch-defining victory over the forces of King Perseus of Macedon at Pydna in 167, the Roman state oversaw the enslavement of nearly three quarters of a million people on or as

\footnotetext{
${ }^{37}$ Polyb. 10.15.4-5, with Erskine (2013, p. 122-4) on the echoes of Thuc. 7.29.4-5.

${ }^{38}$ Genocide in Greco-Roman antiquity: van Wees (2010); Quesada-Sanz (2015); Konstan (2018).

${ }^{39}$ Sacking narratives: Westington (1933); on the lexicon and praxis of Roman city-sacking, Ziolkowski (1993). Battlefield finds: see e.g. Ribera i Lacomba and Calvo Gavez (1995) on the destruction of Iberian Valentia during the Sertorian War.

${ }^{40}$ Cf. the differential treatment of captives in small-scale North American indigenous communities: Cameron (2016, p. 51-2). For application of this principle to the study of Roman slavery see the forthcoming work of Katharine Huemoller.
} 
a direct consequence of battlefield activity. ${ }^{41}$ Once secondary mechanisms for enslavement - such as those borderlands transactions whose archaeological imprint in pre-Roman Gaul has been investigated by Michael Dietler - are factored in, the number of enslaved is likely to have cleared the million-person threshold. Enslavements continued to glut the Roman labor force for the next century and a half after Pydna, cementing Rome's status as a slave society. ${ }^{42}$ Shifts in Roman agricultural and commercial production during the $2^{\text {nd }}$ and $1^{\text {st }}$ centuries BCE, above all the Italian peninsula's rising prominence in wine production and export, were not only tied to but in fact almost wholly dependent on the exploitation of slave labor at scale. By the dawn of the Principate in the 20s BCE, following two decades of civil and Mediterranean-wide war, millions of enslaved persons lived and suffered throughout the Roman Mediterranean. ${ }^{43}$

Although some enslaved persons resided in urban contexts whose basic outlines we can reconstruct and about which we are relatively well informed, and from which inscriptions commissioned by or referencing their activities have been recovered, the overwhelming majority labored in miserable and anonymizing subjection on farms, quarries, and mines, with only the occasional inscription or artifact alerting us to their presence. Many of these enslaved persons were under considerable constraints when it came to the affirmation of those cultural practices that had defined their lives prior to slavery, as the airing of concerns about these practices in Cato the Elder, Varro, and Columella discloses. ${ }^{44}$ These concerns gesture to a basic fact about Roman mass enslavement, which is that it sought to consume not only the bodies of the enslaved, but their minds as well. Slavery was a technology for epistemic exploitation and, where necessary, suppression. To lay bare the operations of this epistemic violence, let me turn first to the evidence for an economic activity that imposed extraordinary and often fatal demands on enslaved persons: metal extraction, especially at those mines in the Iberian Peninsula whose management was contracted out to private outfits following Rome's conquest of the region.

Iberian mining's exemplification of the interaction between imperially fueled slaving and ecological exploitation makes it an exceptionally attractive candidate for the line of analysis pursued in this article, ${ }^{45}$ though other case studies would not be hard to find. So

\footnotetext{
${ }^{41}$ Etymology: Dig. 50.16.239.1 (Pomponius). Estimate: Scheidel (2011).

42 Moses Finley's "slave society" model has attracted much debate and no small amount of disagreement; for recent efforts to modify and nuance the scheme see the contributions in Lenski and Cameron (2018).

${ }^{43}$ The dynamics of the Roman slave supply in the centuries after the Republican mass enslavements: Scheidel (1997), with some adjustments in Scheidel (2011); note also Scheidel (2005).

${ }^{44}$ For specifically religious concerns see Padilla Peralta (2017a).

${ }^{45}$ Important literary testimonies for mining operations in the Peninsula: Diod. 5.38.1 and Strabo 3.2.811, both of which draw some of their content from Posidonius. For the latter's debt to Agatharchides' description of the Ptolemaic gold mines see Strasburger, 1965, p. 48-9; cf. Bosak-Schroeder (2020, p. 44-5) on mining in Diodorus. Synthesis of the literary and archaeological evidence for Iberian mining: Hirt (2010).
} 
much silver was mined in Spain during the Roman period that the lead pollutant by-product of this extraction has left a lasting environmental signature, detectable in Greenland icecores, the lakes of Sweden and Russia, and bogs in Switzerland and Spain itself. ${ }^{46}$ This exploitation relied not on motorized or automated technology but on slave biopower as its foundation and primary component. The number of laborers forced into this bonegrinding and ultimately fatal enterprise will have been massive, especially following Cato the Elder's imposition of tax on Iberian metal-extraction enterprises in the first decade of the second century. ${ }^{47}$ According to the eyewitness testimony of Polybius, who visited the mines outside of Carthago Nova sometime in the middle of the second century, 40,000 workers were required for the production of 35 tons of silver a year, for which 140,000 tons of ore will have had to be extracted and purified. ${ }^{48}$ These are the figures for only one site in the mid- $2^{\text {nd }}$ century, one whose production would soon be eclipsed by the much larger extraction operations for silver and copper at the Rio Tinto. The cultural ripple-effects of this unprecedented exploitation of humans and metals were felt within the first few decades of the Roman conquest, on several levels. For one, already in Polybius's lifetime, the demands of the mines intersected with Roman taxonomies of enslavement, with metalli ("metal men") making their appearance on the Roman stage. ${ }^{49}$ The tragic contrast between the fantastic wealth that accrued to those who owned these mines and the near-certain and agonizing deaths of those who worked them would later attract commentary from one of Polybius's historiographical successors. ${ }^{50}$

But the extraction of Iberian metal did not result solely in the physical destruction of the enslaved, or in Greek and Roman literature's subsequent meditation on that destruction. It also resulted in epistemicide. One incident from $150 \mathrm{BC}$ marks a turning-point in the Roman conquest's epistemicidal trajectory. That year, the praetor Ser. Sulpicius Galba ordered the slaughter and enslavement of several Lusitanian tribes that had placed themselves under his protection. ${ }^{51}$ Massacres of this kind were not atypical of Rome's penetration into the Iberian Peninsula. ${ }^{52}$ On Galba's return to Rome and prosecution on a capital charge for unauthorized killing and slaving, he alleged either that the Lusitanians were planning to attack him, or that

\footnotetext{
${ }^{46}$ Hong et al. (1994); García-Alix et al. (2013); McConnell et al. (2018).

${ }^{47}$ Liv. 34.21.7 with Richardson (1996, p. 73). Cato the Elder's eye for the peninsula's (extractable) resources: FRHist F116.

${ }^{48}$ Polyb. 34.9.8-9 with Kay (2014, ch. 3) on the numbers. The Roman takeover of Carthaginian slaving operations in the area: Flaig (2009, p. 55-6); Lewis (2018, p. 266).

${ }^{49}$ See Accius Ann. 3 Dangel (calones famulique metallique caculaeque) with Čulík-Baird (2020, p. 179-80).

${ }^{50}$ Diod. 5.38 .1 on the wealth and misery.

${ }^{51}$ App. Ib. 59.245-60.255 for the fullest account of Galba's activity; cf. Val. Max. 9.6.2 and Orosius 4.21.10. Galba's prosecution at Rome: Cato the Elder FRHist F104-7 and Liv. Per. 49.17-20, the latter with the important detail that Galba sold those whom he did not slaughter into slavery. Roman militarism in mid- $2^{\text {nd }}$ century Iberia: Richardson (1996, p. 60-4); cf. Cadiou (2008, ch.1) for the balancing of diplomacy and shows of force.

${ }^{52}$ The archaeological evidence is summarized in Quesada-Sanz (2015, p. 14-20).
} 
they had sacrificed human beings, or that they had performed a ritual act of human sacrifice as a prequel to attacking him. ${ }^{53}$ While representative of the tendency among historians of the conquest to differentiate between "good" and "bad" governors, ${ }^{54}$ this muddle of literary testimonies points to a fog-of-war scenario in which Galba misconstrued a ritual act by one of the tribes as a sign of imminent attack; numerous parallels from borderlands conflicts in the Americas suggest themselves. More pertinent to our purposes, however, is what the Roman overreaction signaled to those individuals and tribes who witnessed the slaughter, or survived it as newly enslaved persons. Not only would the raw traumas of Roman violence have left a deep impression; Galba's actions conveyed in no uncertain terms the message that Lusitanian religious rituals and way of life were thenceforth to be policed, with some being deemed worthy of extirpation. An echo of this monitoring is detectable in the Augustanera geographer Strabo's critical report on Lusitanian divinatory and cultic observances, ${ }^{55}$ whose contours came into clearer focus at the same time that the first princeps prosecuted those military campaigns and colonization programs through which Iberia was rendered even more exploitable.

The fate of the Iberian Peninsula in the age of the conquest shares some striking affinities with Kathryn Yusoff's beguiling characterization of the early modern Euroimperialist system as "an indifferent extractive geo-logic that is motivated by the desire for inhuman properties. Indigenous genocide and settler colonialism are also part of these extractive geo-logics." ${ }^{56}$ Both of these processes took shape around Rome's assertion of hegemony over Hispania. Where did the bodies for the Iberian mines and their fatal work of extraction come from? At first, largely from the Iberian Peninsula itself, enslaved through the work of ministers of devastation such as Galba; later, from other corners of the Mediterranean, and almost certainly from the Gallic borderlands that had been a zone for human trafficking well before Caesar appeared on the scene. It was in the vortex-drain of an imperially amplified mining network that communities (and cultures) went to die. In modern accounts of the Roman conquest of Iberia, Strabo's report that the Turdetanians of southern Iberia had adopted Roman ways so completely as even to forget their own language has regularly been cited as evidence for the efficacy and rapidity of the region's Romanization. Even though some scholars have proposed to read this notice as implicated in a "colonial discourse on the conquest and 'civilization' of peoples under Roman control" that mobilized topoi of the kind that we saw earlier with Aristoxenus, ${ }^{57}$ one should not rush to dissociate this discourse from the experiences of communities on the ground. Languages were lost and cultures altered in the wake both of the Roman conquest and of the follow-up operations of wealth extraction, chief among them the conversion of human bodies into metal wealth, through which the conquest's legacy was cemented.

\footnotetext{
${ }^{53}$ Human sacrifice: Plut. QR 83 with Scheid (2012, p. 162), identifying the Bletonesii as Lusitanians.

${ }^{54}$ On this historiographic tendency see Cadiou (2008, p. 64-5).

${ }^{55}$ Strabo 3.3.6 with Lozat (2019, p. 101-2).

${ }^{56}$ Yusoff (2018); cf. Galeano (1971).

${ }^{57}$ Thus Jiménez (2011, p. 506-7), commenting on Strabo 3.2.15.
} 
More than the physical labor of the enslaved was required to run these mines, and to sustain the vast network of commercial, political, and ecological relations that facilitated their intensified exploitation. ${ }^{58}$ Across an array of activities both within and beyond the Peninsula, the interrelationship of mass enslavement, wealth extraction, and the raiding and ransacking of localized knowledges comes into view. That the Romans were not afraid to commandeer the expertise of conquered and enslaved populations for their own highly lucrative ends is surely one of the more incontrovertible takeaways from Pliny the Elder's thirty-seven-book Natural History. Moreover, the practice of appointing specific communities to supply Rome with viatores and scribae is emblematic of the imperial fantasy of converting the subordinated into instruments for the aggregation of knowledge. ${ }^{59}$ However, this fantasy reached fruition not only through positive accumulation, but through systematic demolition as well. Those Roman leaders who invested in infrastructures for the exchange of cultural knowledge in conquered regions were not chasing after epistemically beneficent outcomes; the school that Sertorius founded for local aristocratic youths at Osca is a case in point. ${ }^{60}$

For this reason, the interaction between slave abjection and epistemic suppression deserves careful scrutiny. Turning away from the Iberian Peninsula to the epistemological features of Roman enslavement more generally, we need to be more precise about how slavery targeted minds as well as bodies. To be sure, slaving and captivity did generate new forms of inter- and intracultural knowledge, which then circulated in oral and written formats. The Plautine palliata's play with the timeliness and untimeliness of letter exchanges foreshadows later Mediterranean slave-systems in which enslavement, ransoming, and captivity were brokered and mediated through epistolary exchanges of information that shone a bright light on the cultures of captive and captor alike. ${ }^{61}$ Even the mines generated scientific knowledge of various kinds, at stunning costs. ${ }^{62}$ However, by severing individuals and communities from the environments in which their identities and knowledges had taken root and shape, mass

\footnotetext{
${ }^{58}$ Gosner (2016) is excellent on the main features of this network.

${ }^{59}$ For this second point see Purcell (2001, p. 665). The need for a comprehensive history of scribae is pressing: that many of them benefited from opportunities for social advancement seems obvious (Hartmann, 2018), but this upward mobility entailed sacrifices, some of which were epistemic in nature. ${ }^{60}$ Plut. Sert. 14.2-3, laced with the biographer's insight that this was a form of hostage-taking. This passage's relevance to the emergence of bilingualism in Hispania: Simón Cornago (2019, p. 81); for other "schools of the Latin liberal arts in the western provinces", Adams (2003, p. 692).

${ }^{61}$ Letters in Plautus: Barbiero (2018); cf. Osgood (2009) on epistolography and conquest in Caesar and Cicero. The traffic in knowledge and enslaved persons as epistolary process in the early modern Mediterranean: Hershenzon (2018, chs. 4 and 6).

${ }^{62}$ See purely e.g. Isid. Etym. 12.3.4 on the solifuga, a spider-shaped creature in Sardinia that was abundant in silver mines and "causes death for those who sit on it inadvertently" (tr. Barney et al., 2006); see Cocco (2019) for synthesis of the evidence on slaving in Roman Sardinia. Pliny NH 29.29.92 may be referring to the same insect when commenting on the words solipuga and salpuga, the latter being the preferred term in Iberian Baetica - another mining region.
} 
enslavement compromised the capacity of millions to hold on to the secure understandings that had previously anchored their ways of being in the world.

One potential rejoinder to this line of reasoning is that the minds of the enslaved were implicated in and responsible for the social and intellectual transformation of Roman society, from the two foundational figures of early Latin literature who rose from slavery to freedom (Livius Andronicus and Terence) to the late-republican and early imperial cast of grammarians and teachers who populate Suetonius's De grammaticis et rhetoribus. ${ }^{63}$ But the prostheticization of "educated" slaves in the service of Roman slavers does not belie or subvert my argument. ${ }^{64}$ If anything, the co-optation of select and highly prized slave intellects for the ends of Roman owners occurred in tandem with and in fact presupposed the refusal to recognize other forms of embodied knowledge. Another potential rejoinder would be that not every species of knowledge was lost: from the comparative evidence of other mass enslavement systems and from the testimonies of Greco-Roman sources themselves, it is obvious that the newly enslaved were able to bring some of their cultural practices with them. But the important point is that vital knowledge was lost in the terrestrial and seaborne traffic of bodies. The story of the freedman playwright Terence's death at sea as he traveled back from Greece with newly translated plays is metonymic of the pervasive crisis of knowledge loss and erasure that swept across the Mediterranean world as it brought to heel by Rome. ${ }^{65}$

This is not to deny the salience of resistance tactics that took shape around those cognitive and artistic resources available to or curated by the enslaved during the period under discussion in this article. If Amy Richlin is correct, early Roman comedy, performed by troupes that consisted largely if not entirely of slaves and freedmen, was imprinted with the experiential and trauma-generated knowledge that the subjected brought with them to venues in Rome and elsewhere in central Italy ${ }^{66}$ But the fact that these generically and performatively bounded forms of knowledge were voiced on the Roman stage does not mitigate or obviate the extent of the epistemic violence inflicted on the enslaved, or the burden placed on their shoulders to be complicit in the reproduction of that violence. José Rabasa has written sparklingly about the ethnosuicide forced by the Spanish conquistadores on colonized Mesoamerican communities in the $1500 \mathrm{~s} .{ }^{67}$ Something akin to ethnosuicide is placed in the mouth of the Virgin of Plautus' Persa, when at the moment of her (mock) sale she responds to the pimp's question "What is your patria?" with a question of her own: "What should it be except the one where I am now?... I reckon everything in the past as nothing, once it's in the past." 68

\footnotetext{
${ }^{63}$ Edition and commentary: Kaster (1995).

${ }^{64}$ Enslaved persons as prosthetic extensions of the enslaver-littérateur. Blake (2012) (the Plinies); Reay (2005) (Cato the Elder); cf. Fitzgerald (2000, ch. 5). The publication of Harriet Flower's study of Daphnis and Joseph Howley's research into Roman book culture and enslaved persons is eagerly awaited.

${ }^{65}$ Suet. VT 5 with Richlin (2017, p. 170-1) on "human cargo and the circulation of art."

${ }^{66}$ Richlin $(2014,2018)$.

${ }^{67}$ Rabasa (2011, esp. ch. 6).

${ }^{68}$ Pers. 636-38, to be read with Richlin (2015, p. 43-4).
} 
In an earlier publication, I argued that the ascription of certain types of divination to the enslaved in some of our Republican literary sources reflects enslaver anxieties about the knowledge that the deracinated and humiliated could and did bring with them, specifically the movements of the enslaved body as $\mathrm{s} /$ he tried to offer worship and cult to the gods of a home now long vanished. ${ }^{69}$ In support of this claim, I made use of anthropological studies of religion in the Middle Passage, quoting at some length the anthropologist Karen McCarthy Brown on the emergence of Haitian Vodou:

When the elders, the priests, the institutions, the musical instruments, the images, the altars, and the sacred objects are absent, where do you turn for a spiritual aid? In an African-based religion, possession seems an obvious answer. In Yorubaland and Dahomey, two of the areas of origin for Haiti's slave population, most possessionperformances were formulaic affairs with more or less predictable words and gestures. In the New World, however, in that early time when the body and the voice were the slaves' principal mnemonic devices, possession could well have received much greater emphasis, and possession-performances could have quickly become much more extemporaneous and expressive. In other words, cut loose from their African base and institutional moorings, the spirits may well have burst into flower. Times of crisis are often times of high creativity. ${ }^{70}$

Her main point, that the conditions of enslavement acted as a spur to religious creativity, might on a first take seem at variance with my determination to locate epistemicide as a core element of slave subjection. However, the catalogue lays bare how such epistemicide will have worked within a system of mass enslavement. For those slaves trafficked to the Roman peninsula and other areas under Rome's thumb, "the elders, the priests, the institutions, the musical instruments, the images, the altars, and the sacred objects" were also absent and in many cases irrecoverably lost. In a posthumously published essay on religious mobility in the Roman Empire, the late Simon Price correctly stressed that "people who travelled sometimes took cults with them". ${ }^{71}$ Sometimes: more often than not, those who were compelled to move did not and could not bring the gods on their backs.

Headlined by a founder-figure who travels with the Palladion to the site of the future city, Rome's own origin-myth gives voice to the fear of not being able to take one's sacred objects to a new home, especially in circumstances of forced migration. Creativity and ingenuity to remedy such loss are of course to be expected and should form part of any account of the inner resilience of the displaced and enslaved, as should their determination to create new communities whose hybridizing material cultures emerged in close dialogue with

\footnotetext{
${ }^{69}$ Padilla Peralta (2017a, p. 336-45).

${ }^{70}$ Brown (2010, p. 253).

${ }^{71}$ Price (2012, p. 8); note also on the same page the claim that "As part of this travelling world, cults and religious objects could be taken anywhere."
} 
multigenerational trauma. In time, the culture(s) of freedpeople would attain enough visibility as to become a force for transformation in Rome itself, impinging upon and in many cases actively conditioning the directions and emphases of elite culture. ${ }^{72}$ Yet this development cannot be taken to offset the near-total destruction of the material and institutional forms within which self- and collective understandings had taken shape among those who were trafficked into slavery and subjection. The chance survival of an incantation here or a charm there should not be taken as representative of the full absorption of the religious thoughtworlds of the subjected into the matrix of imperial power, ${ }^{73}$ but rather as floating fragments of ways of being that were otherwise pulverized into oblivion.

Those ethnographic testimonies of the oikoumene as filtered through the imperial Roman gaze disclose the extent to which the practices of populations that came under Roman rule were rendered increasingly unknowable as imperial expansion erased the cultural contexts for their performance and transmission. Julius Caesar's digression on Celtic customs and religious observances in the De Bello Gallico, and notably his report on the world-making and interpretive practices of male "priests" (Druids), have been sifted repeatedly for insight into the cultural world of the Celtic populations on the receiving end of coordinated largescale assault, and into Roman refractions of this cultural world. ${ }^{74}$ Not often acknowledged is that the process of knowledge acquisition on display in Caesar's excursus seduces modern readers into patterning their own inquiries into Gallic religiosity along its own terms and discursive techniques - textualization foremost among them - to the point that the religious frameworks within which Gallic women operated (not interesting in the slightest to Caesar in Gaul or his protégé Sallust) become invisible as they ascend the mountain. ${ }^{75}$ Rooted in militarized reconnaissance and enslavement, Roman ethnography was an important player in the perpetration of epistemicide, ${ }^{76}$ both by selecting only those perspectives and knowledges that were already legible within its own system and by all but ensuring that later consumers of this ethnography would not be in a position to grasp the pervasiveness of the silencing act by which non-legible knowledges were heaved into the dust bin. Caesar's $B G$ does not summon to life "the internal diversity of language, practices, and institutions among the peoples of Gaul alluded to in the opening paragraph of the work" because its ordering

\footnotetext{
${ }^{72}$ MacLean (2018) on this process in the early Empire.

${ }^{73}$ For Cato's incantation see De agricultura 160 with Padilla Peralta (2017a, p. 347-8) and bibliography cited at n. 142; cf. Ager (2019) on Columella's caterpillar charm.

${ }^{74}$ Ethnographic digressions in Caesar's BG: Creer (2019). The BG and the unreliability of the Roman ethnographic gaze: Riggsby (2006, p. 123-4).

${ }^{75}$ For the ritual practice of Gallic women see Sallust Hist. 4.29 Ramsey $=40$ M., to be read together with Plut. Crass. 11.5 and Ernout (1925). Caesar's weaponization of textualized literacy against Gallic communities: Osgood (2009); cf. Johnston (2017a, p. 87-8).

${ }^{76}$ Cf. Harrison (2019) on enslavement's role in the evolution of Greek ethnography.
} 
principle is an epistemicidal one: to afford "occasional glimpses into local customs" while subordinating Gallic culture as a whole to Roman ratio and scientia. ${ }^{77}$

Crafted through dialogue with the ethnographic principles and procedures of Greek historiography, Roman ethnography manifested from its earliest stages an active interest in distinctive environmental and ecological regimes. This is no accident: Roman writers were so preoccupied with local habitats partly because the Roman state kept altering them. Although seared upon every level of Roman culture, the effects of ecological ravage and exploitation are most acutely marked in the realm of knowledge and knowledge production. It is to this brand of epistemicide that I turn next.

\section{ECOlogical CALAMITY AND EPISTEMICIDE}

We are taught to recognize fish, see and consider its relationship to bear, and this leads us to the medicine ways of bear. We watch bear fertilize the mountains and the berries and understand bear's value to the earth. We watch mosquitoes rise from the swamp and become food for birds and bats, and their waste becomes food for berries, and berries become food for us, so we honour them. We understand that we have a relationship with these mosquitoes, these berries, these fish. [...] We honour this relationship and permit these beings to teach us to acquire the necessities of life in the least obtrusive way possible.

Lee Maracle, Memory Serves (2015, p. 25)

Ecological violence was a mainstay of Mediterranean conflicts well before the Romans appeared on the scene: the Spartan destruction of Athenian orchards and crops during the Peloponnesian War or the ravaging of trees and orchards in the Sicilian conflicts of the early $4^{\text {th }}$ century are among the most notable episodes. ${ }^{78}$ But the scale and duration of Rome's ecological vastitas in times of war and peace had no Mediterranean precedents. Even as a new generation of scholarship queries the gap between the infrastructural boasts of ancient states and their realities on the ground, the deep penetration of the Roman state

\footnotetext{
${ }^{77}$ Here I am both quoting and rewriting Johnston (2017a, p. 88). Cf. Riggsby (2006, ch. 3 and esp. p. 101) for the $B G$ 's characterization of the Gauls as borrowing technologies from the Romans - but not the other way around - and of the Germans as non-technological.

${ }^{78}$ Purely e.g., Thuc. 2.54.1; Diod. Sic. 14.48.5. The second episode and its implications for the economic history of early Hellenistic Sicily: Fentress (2013, p. 168-9). Greco-Roman militarism and the environment: Hughes (2014, ch. 9).
} 
into the ecologies and landscapes of the Middle Sea is not up for question. ${ }^{79}$ Publication after publication has documented the avidity with which agents of the Roman state pursued infrastructural projects that were unabashedly and self-consciously preoccupied with altering the environment. ${ }^{80}$ While the most monumental of these alterations came in for critique within literary discourses of luxuria, ${ }^{81}$ the cognitive aftershocks are mostly passed over in silence. What I propose to do in this section is sketch the relation between environmental transformation and epistemic loss.

As Romans were busy killing human beings, they also applied themselves to the transport and relocation of non-human species. The "comestible historiography" of the late Republic and early Empire maps several transformations in culinary practice to imperial expansions of the last few centuries BCE, chiefly in connection with the introduction of new fruit and nut trees. ${ }^{82}$ The consolidation of Roman hegemony over peninsular Italy lines up well with the chronology for an escalating regional increase in beef and beef consumption, a dietary change in the lives of millions that has been corroborated by the faunal record. A secondary faunal signature of the Roman Empire's ecological intervention was the spread of fallow deer throughout the western Mediterranean. ${ }^{83}$ Another charming animal's travel on the coattails of Roman expansion left a vestigial trace in Latin literature: the same cuniculi that followed Marcus Terentius Varro back to Rome from Hispania also seem to have jumped across the water from the Iberian Peninsula to the Balearic Islands, so much so that the islands' residents desperately petitioned Augustus for help against their proliferation. ${ }^{84}$ On a much less charming note, mice and rats also rode the waves of Roman imperialism, with ultimately disastrous consequences in the first few centuries CE. If one celebrated literary notice about a horse pestilence is rooted in historical fact, epidemiological crisis on one of Rome's frontiers during our period had a profound impact not only on local animal populations but on the human cultural practices that were attached to them. ${ }^{85}$ While J. R. McNeill has rightly called attention to the pax Romana as one of the four watershed moments

\footnotetext{
${ }^{79}$ Infrastructural power: the essays in Ando and Richardson, 2017. The notion that environmental degradation occurred under Roman eyes used to be greeted with skepticism, but the evidence for deforestation is hard to miss: see Sallares (2008, p. 21-6 and n. 92-4 below).

${ }^{80}$ Purcell (1990, provincial landscapes), (1996, hydraulic engineering).

${ }^{81}$ See e.g. the moralizing commentary on stone extraction and Roman luxury: Strabo 12.8.14; Pliny NH 36.1.1-2.

${ }^{82}$ Quoted phrase and discussion: Purcell, 2003. Fruit and nut trees and the "east to west movement of useful plants": Sallares (2008, p. 29-30).

${ }^{83}$ Mackinnon (2018, p. 101).

${ }^{84}$ Varro's bunnies: RR 3.12.7. The petition: Pliny NH 8.81.218.

${ }^{85}$ See Verg. Georg. 3.498-501 with Dyson (1985, p. 62-3) on the horse pandemic among the Veneti; Strabo 5.1.4 with Roller ad loc. on the resulting decline in horse-breeding, in an area previously famous for its equines.
} 
in the premodern global history of "biological exchange", ${ }^{86}$ the downside to this exchange in the Roman Mediterranean was the erosion of local biodiversity.

Any narrative of ecological alteration's place in the historical sweep of Roman epistemicides should begin with the mechanism for structured human displacement that ran on some of the same circuits as mass enslavement and operated at similar orders of magnitude: large-scale settler-colonialism, first in the Italian peninsula and then in the Roman Mediterranean, which impacted both the human beings set in motion by the colonial program and the environments with which they interacted. Accelerating in the final decades of the fourth century BCE, the Roman state's flurry of colonial displacements incrementally overhauled internal peninsular relations and, in due course, the political and economic networks of the greater Mediterranean. ${ }^{87}$ By and large, scholars have characterized this movement as a (mostly) volitional migration of Romans and Latins to locations that had been chosen for their strategic advantage and as safety valves for the release of demographic pressures building up within and in close proximity to the city of Rome. Although archaeologically informed research is now forcing reassessment of the traditional material indices for tracking this development, it is the status of this large-scale human mobility as a voluntary migration (or wave of voluntary migrations) that is most sorely in need of interrogation. Evan Jewell has recently argued that the "Roman colonization project" was not so much a case of volitional migration as of forced displacement, especially of the economically distressed and socially marginal. ${ }^{88}$ Clear-cut instances of forced displacement abound in the Roman historical record, most infamously the relocation of Apuan Ligures from their ancestral home in northwest Italy deep into Samnium during the early decades of the second century. ${ }^{89}$ But Jewell's point is that the operation of settler-colonialism on Italian soil consistently depended on harrowing and traumatizing displacements. These displacements bred resistance, in the form both of outright rebellion (such as Fregellae's insurrection against Rome in $125 \mathrm{BCE}$ ) and of colonial depopulation, whenever the first bands of settlers melted away to return home.

One necessary condition for (and outcome of) the massive displacement and resettlement of hundreds of thousands of people was the alteration of landscapes. By the closing decades of the fourth century, the Roman state was overseeing various types of land reclamation projects, from the draining of marshland for the construction of roads to the intensifying appropriation and re-distribution of water resources, beginning with the construction of the Aqua Claudia. Unsurprisingly, it was also capitalizing if not already cashing in on access to salt-beds. ${ }^{90} \mathrm{By}$ the mid-third century at the latest, another ecological shift was under way: deforestation, driven not only by the need to clear arable land for a growing

\footnotetext{
${ }^{86}$ McNeill (2003, p. 35-6).

${ }^{87}$ Demographic parameters of colonization's displacements: Scheidel (2004).

${ }^{88}$ Jewell (2019).

${ }^{89}$ Livy's narrative of this displacement: Sehlmeyer (2018), comparing the deportation to the Trail of Tears.

${ }^{90}$ Mid-republican exploitation of salt-beds: Purcell (1996, p. 190-3).
} 
population but by escalating demands for fuel (in the form of wood and charcoal) and naval armaments. The archaeologist Robyn Veal has led the charge for a fuller reassessment of Roman deforestation's economic and political impacts. ${ }^{91}$ While forest exploitation is well documented for both the classical and Hellenistic Greek worlds, ${ }^{92}$ the practice's intensification in the wake of the Roman expansion resulted in wide-ranging ecological and epistemic consequences, heralded by a more pronounced concern with maintaining sacred groves.

Already by the end of the fourth century BCE, numinous woodland enclosures were a site of regulation and contestation precisely because of the menace posed by the rising demand for wood commodities was so real. Some decades later, in the early stages of Latin literature's emergence, Italic groves and forests assume positions of prominence, not only as objects of the ethnographic gaze (in Cato the Elder's Origines) but as markers of potential or actual religious transgression (in Ennius' Annales). Latin epic's enduring engagement with the numinousness of forests and other landscapes under siege from the engines of empire demands to be read as a poetics of worry, formulated and sharpened to mediate the aesthetic and cultural impacts of human manipulation of the environment. But this poetics of worry masks a deeper and ultimately irreversible disruption, only partially arrested by some of the forward-thinking conservationist strategies of the High Empire. ${ }^{93}$ With ecological upheaval came the effacement of locally configured and disseminated knowledge of the gods.

If, as several scholars have strongly urged, we think of Roman and Italic religions as religions of place, then it stands to reason that the destruction of specific places entailed, quite literally, the destruction of certain religious forms that were attached to and articulated through local communities: epistemicide. Among the various notices in the literary tradition of emergent Roman awareness of this phenomenon, one stands out for the lucidity with which the relationship between ecological vulnerability, imperial exploitation, and religious awareness is treated. The notice, in Tacitus' Annals, concerns an incident in $15 \mathrm{CE}$. Two Roman senators, C. Ateius Capito and L. Arruntius, proposed to minimize the flooding of the Tiber - one secondary outcome of extensive upstream deforestation - by diverting its tributary sources. ${ }^{94}$ I quote the passage in full:

Actum deinde in senatu ab Arruntio et Ateio an ob moderandas Tiberis exundationes verterentur flumina et lacus, per quos augescit; auditaeque municipiorum et coloniarum legationes, orantibus Florentinis ne Clanis solito alveo demotus in amnem Arnum transferretur idque ipsis perniciem adferret. congruentia his Interamnates disseruere: pessum ituros fecundissimos Italiae campos,

\footnotetext{
${ }^{91}$ See, e.g., Veal (2017).

${ }^{92}$ Meiggs (1982) collected the evidence; Amigues (2007, p. 108-21) for a new evaluation of the literary testimonies; Hughes (2014, ch. 5) for a synoptic assessment.

${ }^{93}$ Note e.g. the Hadrianic boundary stones that cordoned off a protected section of the cedar forests on Mount Lebanon: Mikesell (1969).

${ }^{94}$ The bearing of this episode on the history of Roman water-projects in central and southern Italy: Keenan-Jones (2013). The incident's religious aspects: Shannon-Henderson (2019, p. 25-30).
} 
si amnis Nar (id enim parabatur) in rivos diductus superstagnavisset. nec Reatini silebant, Velinum lacum, qua in Narem effunditur, obstrui recusantes, quippe in adiacentia erupturum; optume rebus mortalium consuluisse naturam, quae sua ora fluminibus, suos cursus utque originem, ita finis dederit; spectandas etiam religiones sociorum, qui sacra et lucos et aras patriis amnibus dicaverint: quin ipsum Tiberim nolle prorsus accolis fluviis orbatum minore gloria fluere. seu preces coloniarum seu difficultas operum sive superstitio valuit, ut in sententiam Pisonis concederetur, qui nil mutandum censuerat.

Next an item was raised in the Senate by Arruntius and Ateius regarding whether, in order to moderate the floods of the Tiber, the rivers and lakes through which it was swelled should be diverted. Embassies from towns and colonies were heard, with the Florentines pleading that the Clanis not be removed from its normal bed and transferred into the Arno river, so that this would not bring disaster upon themselves. There was similarity in the matters that the Interamnates discussed, stating that the most fertile fields of Italy would be ruined if the river Nar, having been led away through channels (for this was being prepared), spread over them and formed a lake. Nor were the Reatines silent, rejecting the damming of Lake Velinus (which there pours itself out into the Nar) after which it would necessarily overflow into the surrounding areas. Nature, they argued, which gave to rivers their sources and their courses, had considered human affairs most carefully: as it gave a beginning, so it gave limits. They further argued that the cults of the allies, which have consecrated sanctuaries, sacred groves and altars to the streams of their native lands, should be respected, and that the Tiber itself did not want to flow onwards with reduced glory, deprived of its tributaries. Either the pleas of the colonies, or the difficulty of the works, or superstition, prevailed such that at the motion of Piso, who had expressed the opinion that nothing should be changed, the plan was abandoned..$^{95}$

On a first read, the outcome of this episode may appear to be at odds with my characterization of the Roman state's capacity for destruction: these specific communities succeeded in deferring an infrastructural program that would have forever altered their landscapes and the full spectrum of cultural practices attached to them. But these communities were the exceptions that prove the rule, since their success was conditional on the fact that they enjoyed sufficient political visibility and connections for their remonstrations to hold weight with the Roman Senate. Isolated incidents of effective resistance such as these obscure the realities of Roman infrastructural domination and its ecological aftershocks throughout

${ }^{95}$ Tac. Ann. 1.76 (tr. Woodman). 
the Mediterranean. What happened to those communities that could not marshal and deploy the connections to persuade the state to relent and leave them alone? Their lands and cults were transformed, more often than not irreparably.

Archaebotanical studies confirm that large-scale population growth sparked and accelerated by Roman imperial expansion and transformation led first to a loss of forest cover in sections of the peninsula and then to secondary effects on local ecologies; recognition of the latter can be discerned in Pliny the Elder's complaint about the disappearance of certain bird species. ${ }^{96}$ The aggressiveness of Roman imperialism's ecological devastation outside of Italy is wrenchingly brought out in a notice in Florus about the Dalmatian Wars. Over several generations, Roman armies brought to heel a hunter-pastoralist tribal configuration first by torching their main settlement; then by stripping them of their flocks, weapons, and lands; finally, by forcing them into mining their own land for precious metals (2.12.10-12). Besides the obvious parallel with the trajectory of those Iberian communities for whom "large-scale mining ... transformed rural landscapes into industrial ones", ${ }^{97}$ this sequence is not radically dissimilar to the fate of Caribbean indigenous communities in the decades after the First Contact. Roughly contemporary with Florus' redaction of his Epitome, an arguably more gutting representation of ecological destruction in the service of empire received visual expression: Trajan's Column depicts Roman soldiers chopping down trees. ${ }^{98}$

It might be objected that these interventions into natural environments were, for all their brutality, generative of new systems of knowledge. Or that they were at the very least regenerative of landscapes that had previously been laid waste by the Roman military machine. ${ }^{99}$ I would not deny this. However, it should be borne in mind that the assimilation of local and indigenous botanical and herbicultural knowledges into the textualized pharmacological epistemes of the Greco-Roman Mediterranean - one thinks of those compilations of plant-based concoctions in the writings of Scribonius Largus, who credited Sicilian hunters for a remedy against snakebite; or Pedanius Dioscorides's five books of Materia medica; or the pharmacological sensibilities of Pliny the Elder himself - was at best an imperfect process. ${ }^{100}$ For every ethnic group that pulled off the feat of translating its local knowledge into a preservable commodity, ${ }^{101}$ many others did not. In some cases, we can even observe how the cultivation of local knowledges by a community under threat

\footnotetext{
${ }^{96}$ NH 10.17 with Padilla Peralta (2018, p. 258-9).

${ }^{97}$ Gosner (2016, p. 130).

${ }^{98}$ The significance of these trees: Fox (2019).

${ }^{99}$ See Beltrán Lloris (2017) on the "regeneration" of the Middle Ebro valley.

${ }^{100}$ For coverage and discussion of empire's imprint on medical texts see Nutton ([2004] 2013, ch. 12); cf. Lloyd (1983, p. 135-49), who argues that the NH's botanical content is mostly lifted from literary sources, and esp. p. 148-9 with n. 102 on Pliny's mistrust or second-guessing of non-literate practitioners. The imperial branding of plants such as Illyrian gentian: Pliny NH 25.34 with Padilla Peralta (2017b, p. 270); cf. Whitt (2009, ch. 3).

${ }^{101}$ See e.g. the entrepreneurial savvy of the Psylloi: Jones-Lewis (2015); cf. Padilla Peralta (2018, p. 254-5).
} 
depended on the elimination of older ways of life. To return once again to the testimony of Florus, the Iberian Asturians who became conversant in the gold- and pigment-rich properties of their region's soil did so only after the emperor Augustus put an end to their mountain pastoralist existence by forcing them to cultivate the plains (2.12.59-60), in another sign of the state-backed preference for farmers over pastoralists whose earliest expression occurs in connection with the Sicilian slave wars. ${ }^{102}$ Coastal communities were not exempted from similar treatment. In the western Mediterranean, the Roman takeover of Greek and Punic maritime harvesting practices led to the rapid multiplication of fish-salting facilities, displacing in the process those seascape epistemologies that did not align with the protoindustrial labor regimen that was required to run them. ${ }^{103}$

Roman ecological priorities manifested themselves not only in the dictation of new or newly intensified agricultural and aquacultural practices to conquered communities, but in the funneling of biodiversity to human spectators in Rome and other cities for urban enjoyment and consumption. Through "botanical imperialism" as well as the traffic in megafauna, the Roman state and its agents acted in calculating fashion to denude local habitats of those exotic species that were most coveted for exhibition at imperial showcases. ${ }^{104}$ Although numerous precedents for this practice in the history of other $1^{\text {st }}$-millennium BCE Eurasian imperial systems can be cited, the scale and duration of Rome's requisitioning and consumption of biodiversity have no obvious peer. In the aggregate and over the long term, the result was a decline in over-procured animal species, and in multiple cases their extinction - a phenomenon of which Romans themselves were quite aware. ${ }^{105}$

That said, for all that the Roman state and its agents could and did directly intervene in local ecologies, epistemicide was also the work of private actors who were incentivized by the Roman expansion, even (or especially) at the frontier margins. Strabo's account of the private exploitation of the Salassian gold mines, which unfolded to the detriment of farmers who saw their water sources contaminated, offers a gripping demonstration of the convergence between the "survival strategy of self-determining producers" and "the opportunistic and enforced strategy of powerful outsiders". It was these outsiders who won out in the end, when the Salassi were mowed down by Augustus' generals and over 40,000 of them were sold into slavery. ${ }^{106}$

\footnotetext{
${ }^{102}$ Note the Polla elogium (CIL I ${ }^{2} 638=$ ILLRP 454) with Purcell (1990, p. 20); cf. Bernard et al. (2014, p. $965-8)$.

${ }_{103}$ Mediterranean fish production and processing prior to the Roman conquest: Bresson (2016, p. 175-87). The scaling up of fish-salting in the Roman West: Marzano (2013, ch. 3, esp. 103-5 with Fig. 19). I borrow the concept of "seascape epistemologies" from Ingersoll (2016).

${ }^{104}$ Quoted phrase and discussion: Pollard (2009). Megafauna: Futrell (1997, p. 24-9) on the Republican origins of venationes and damnationes ad bestias; Bell (2004, ch. 6) on the politics of megafaunal display. ${ }^{105}$ The "impoverishment of biodiversity" in the Roman world: Hughes (2003, p. 26) for citations and 30 for "conservation" attempts; note esp. Cic. Ad fam. 2.11 .2 with Shelton (2014, p. 473).

${ }^{106}$ Strabo 4.6.6-7, to be read with Purcell (2017, p. 87-9) (whom I quote).
} 


\section{CONCLUSION}

Historico-structural dependency, in the narrative of the modern/colonial world-system, presupposes the colonial difference. It is, indeed, the dependency defined and enacted by the coloniality of power. Barbarians, primitives, underdeveloped people, and people of color are all categories that established epistemic dependencies under different global designs...

W. Mignolo, "The geopolitics of knowledge" (2002, p. 84-5)

Skeptical readers might contend that some marginalized cultures survived despite empire's ravages; or that the brutality was not nearly as sweeping as I have characterized it; or that continuity and perseverance should receive more emphasis. ${ }^{107}$ Undeniably, hybridity and creolization enabled communities on the receiving end of Roman expansionist violence to adapt to changeable and highly fluid imperial dispensations whenever armed resistance was not an option. One thinks of the Judaeans, and of Jewish communities outside of Palestine; or, in the case of the western Mediterranean, those Celtic communities whose investment in aetiological narratives of continuity has been examined with painstaking care in Andrew Johnston's work. ${ }^{108}$ But the success of scattered communities in carefully cultivating a "landscape of resistance" 109 as a counter to Roman hegemonic and epistemic projection should not blind us to the fate of many other groups that were denied the time or the good fortune to practice tactics of accommodation. And even if the survival of isolated cultural clusters in the Roman Mediterranean stands out by comparison to state-formation outcomes at the other end of Eurasia, ${ }^{110}$ attenuated survival is hardly the equivalent of flourishing. In any case, those communities that did not pursue textualization as a strategy for the codification and transmission of their cultural identities almost invariably disappeared from the record (and even textualization hardly guaranteed epistemic survival). ${ }^{111}$ As for the ethnic groups that succeeded in fashioning a cultural logic for themselves under the pressure of Roman exploitation, fictions of continuity often supplied a means of coping with the trauma of knowledges and people lost - but it must be remembered that these were fictions.

\footnotetext{
${ }^{107}$ See e.g. Terrenato $(2019$, ch. 6) for a reassessment of the violence that accompanied the early Roman expansion's brutality; Daubner (2019) on Macedonian survival and adaptation in the century after Pydna.

${ }^{108}$ Johnston (2017b, esp. chs. 3-4).

${ }^{109}$ I borrow this phrase from Häussler 2015's study of the persistence of "indigenous" cultic practices in Cisalpine Gaul.

${ }^{110}$ Note on this issue Scheidel (2019, ch. 9).

${ }^{111}$ Cf. the slippage between script/language/culture in Geller (1997, p. 45-6).
} 
It may also be objected that indigeneity is not a conceptual-historical category with traction for the ancient Mediterranean, and that as a result my reliance on a theory with deep roots in the early modern and modern traumas of indigenous and First Nations communities is underpowered. To this I would reply that it is important not to lose sight of the spectacularly murderous success of early modern European colonizers in deriving and honing a script for the production of indigeneity out of Greco-Roman texts. The legacies of their epistemic violence, which claimed both its rationales and its literary and bureaucratic forms from colonial rehabilitations of Roman imperialism, justify not only the broader project of indigenizing Classics, but a more sustained engagement with those scholars of early modern and modern indigenous experience and memory whose adeptness at identifying the primary vectors for epistemic trauma has much to offer ancient history. ${ }^{112}$ Take, for example, the aforementioned work of José Rabasa on the epistemic traffic between European invaders and Mesoamericans in the decades after the First Contact, evocatively entitled Tell Me The Story of How I Conquered You. The process under examination in Rabasa's monograph has numerous and disquieting parallels in the eastern Mediterranean as it came under Roman rule, as multiple Hellenized writers sang the praises of their conquerors in a bid for cultural preservation. ${ }^{113}$

Two decades ago, Ian Morris claimed that the near-total invisibility of female and slave practices in Athenian material culture was the direct result of a coordinated and calculated hegemonic practice: "Women and slaves remain invisible not because of the inevitable methodological problems with attributing gender and legal status to excavated remains, but because Athenian male citizens wanted it that way." ${ }^{114}$ In the years since, scholars of ancient material culture and slavery have grown much better at retrieving signs of slave presence and agency from the archaeological and literary archives. However, Morris's general proposition seems to me both to hold true and to have equal if not more applicability to the Roman case: the knowledges of the enslaved and subjugated remain largely invisible to us because Roman slavers wanted it that way. And if, as Michael Dietler has reminded us, "colonial encounters transform all parties involved", ${ }^{115}$ we should be more sensitive to the possibility that the effects of Roman epistemicide were not confined to the Mediterranean under Roman rule but extend to us as well. Whether consciously or not, all Roman historians labor in the shadows of Roman knowledge destruction. This article has therefore staked itself to epistemicide not only out of a belief in the concept's theoretical fecundity, but in the hope of alighting on a path towards a more self-reflexive alliance of history and epistemology.

\footnotetext{
${ }^{112}$ Rationales and forms: Pagden (1986). Indigenizing Classics: Blouin et al. (2019). Bosak-Schroeder (2020) is the rare example of a classicist in conversation with Indigenous thinkers.

${ }^{113}$ Rabasa (2011); Padilla Peralta in progress probes Rabasa's utility for re-reading Polybius, Dionysius of Halicarnassus, and Plutarch. Specifically on Dionysius of Halicarnassus see Peirano (2010).

${ }^{114}$ Morris (1998, p. 220).

${ }^{115}$ Dietler (2010, p. 10).
} 


\section{REFERENCES}

ADAMS, J. N. Bilingualism and the Latin language. Cambridge: Cambridge University Press, 2003.

ADORNO, T. Negative dialectics. Tr. E. B. Ashton. London: Routledge, [1966] 1990.

AGER, B. Magic and genre in Columella's caterpillar charm. Classical Pbilology, 114, p. 197217, 2019.

AMIGUES, S. L'exploitation du monde végétal en Grèce classique et hellénistique. Essai de synthèse. Topoi, 15.1, p. 75-125, 2007.

ANDO, C. Vergil's Italy: ethnography and politics in first-century Rome. In: LEVENE, D.; NELIS, D. (eds.) Clio and the poets. Leiden: Brill, 2002, p. 123-42.

ANDO, C. Hannibal's legacy: sovereignty and territoriality in Republican Rome. In: HÖLKESKAMP, K.-J.; KARATAŞ, S.; ROTH, R. (eds.) Empire, hegemony or anarchy? Rome and Italy, 201-31 BCE. Stuttgart: Franz Steiner, 2019, p. 55-81.

ANDO, C.; RICHARDSON, S. (eds). Ancient states and infrastructural power: Europe, Asia, and America. Philadelphia: University of Pennsylvania Press, 2017.

ANDERSON, G. The realness of things past: ancient Greece and ontological history. Oxford; New York: Oxford University Press, 2018.

ANDREAS, P. Drugs and war: what is the relationship? Annual Review of Political Science, 22, p. 57-73, 2019.

BALLESTEROS PASTOR, L. Pompeyo Trogo, Justino y las críticas a Roma: a propósito del discurso etolio (Iust. XXVIII 2). Mediterraneo Antico, 12.1-2, p. 381-92, 2009.

BARBIERO, E. A. Myth, letters, and the poetics of ancestry in Plautus' Bacchides. Ramus, 47.1, p. 2-26, 2018.

BARCHIESI, A. Bellum Italicum. L'unificazione dell'Italia nell'Eneide. In: URSO, G. (ed.) Patria diversibus gentibus una? Unità politica e identità etniche nell'Italia antica. Pisa: ETS, 2008, p. 243-60.

BARNEY, S. A.; LEWIS, W. J.; BEACH, J. A.; BERGHOF, O. (eds. and tr.) The Etymologies of Isidore of Seville. Cambridge: Cambridge University Press, 2006.

BARRANDON, N. Les massacres de la République romaine. Paris: Fayard, 2018.

BELL, A. Spectacular power in the Greek and Roman city. Oxford: Oxford University Press, 2004.

BELTRÁN LLORIS, F. War, destruction, and regeneration in the middle Ebro valley (1st century BCE): the foundation of the colonia Caesar Augusta and its irrigation programmes. In: DERRON, P. (ed.) Économie et inégalité: ressources, échanges et pouvoir dans l'antiquité classique. Vandoeuvres: Fondation Hardt pour l'étude de l'antiquité Classique, 2017, p. 161-95.

BENNETT, J. Vibrant matter: a political ecology of things. Durham and London: Duke University Press, 2010. 
BERNARD, S.; DAMON, C.; GREY, C. Rhetorics of land and power in the Polla inscription (CIL I² 638). Mnemosyne, 67, p. 953-85, 2014.

BLAKE, S. Now you see them: slaves and other objects as elements of the Roman master. Helios, 39.2, p. 193-211, 2012.

BLOUIN, K.; MCMASTER, A.; MEBAN, D.; YUZWA, Z. Indigenizing Classics: a teaching guide. Everyday Orientalism, 2019. Available at: https://everydayorientalism.wordpress. com/2019/05/23/indigenizing-classics-a-teaching-guide/.

BOSAK-SCHROEDER, C. Other natures: environmental encounters with ancient Greek ethnography. Berkeley: University of California Press, 2020.

BRESSON, A. The making of the ancient Greek economy: institutions, markets, and growth in the citystates. Tr. S. Rendall. Princeton and Oxford: Princeton University Press, 2016.

BROWN, K. McC. Mama Lola: A Vodou priestess in Brooklyn. 3rd edition. Berkeley: University of California Press, 2010.

CADIOU, F. Hibera in terra miles. Les armées romaines et la conquête de l'Hispanie sous la République (218 - 45 av.J.-C.). Madrid: Casa de Velázquez, 2008.

CAMERON, C. M. Captives: How stolen people changed the world. Lincoln, Nebraska: University of Nebraska Press, 2016.

CANFORA, L. The vanished library. Tr. M. Ryle. London: Hutchinson Radius, 1989.

CHAKRABARTY, D. Provincializing Europe: postcolonial thought and historical difference. Princeton: Princeton University Press, 2000.

CLACKSON, J.; HORROCKS, G. The Blackwell history of the Latin language. Malden and Oxford: Wiley-Blackwell, 2007.

COCCO, M. B. La schiavitù nella Sardinia. Sintesi dei dati alla luce della documentazione letteraria ed epigrafica. In: DONDIN-PAYRE, M.; TRAN, N. (eds.) Esclaves et maîtres dans le monde romain. Expressions épigraphiques de leurs relations. Rome: École française de Rome, 2016, p. 298-318.

CONNELL, R. Untitled review: B. de Sousa Santos, Epistemologies of the South: justice against epistemicide. AJS, 120.3, p. 949-51, 2014.

CRAWFORD, M. H. Republican denarii in Romania: the suppression of piracy and the slavetrade. JRS, 67, p. 117-24, 1977.

CREER, T. Ethnography in Caesar's Gallic War and its implications for composition. CQ, 69.1, p. 246-63, 2019.

ČULÍK-BAIRD, H. Staging Roman slavery in the second century BCE. Ramus, 48.2, p. 174$97,2020$. 
DAUBNER, F. 'What on earth became of them all?' Continuity and change in Macedonian society after the Roman conquest. In: PEREGO, E.; SCOPACASA, R.; AMICONE, S. (eds.) Collapse or survival: micro-dynamics of crisis and endurance in the ancient central Mediterranean. Oxford: Oxbow, 2019, p. 139-54.

DENCH, E. From barbarians to new men: Greek, Roman, and modern perceptions of peoples of the central Apennines. New York: Clarendon Press of Oxford University Press, 1995.

DENCH, E. Beyond Greeks and barbarians: Italy and Sicily in the Hellenistic age. In: ERSKINE, A. (ed.) A companion to the Hellenistic world. Malden: Wiley-Blackwell, 2003, p. 294-310.

DE SANTIS, G.; AMES, C. La memoria histórica de la diversidad étnica italiana en Eneida de Virgilio. Circe, 15, p. 41-54, 2011.

DIETLER, M. Archaeologies of colonialism: consumption, entanglement, and violence in ancient Mediterranean France. Berkeley: University of California Press, 2010.

DUMM, T. L. Political theory for losers. In: FRANK, J. A.; TAMBORNINO, J. (eds.) Vocations of political theory. Minneapolis: University of Minnesota Press, 2000, p. 145-65.

DYSON, S. The creation of the Roman frontier. Princeton, New Jersey: Princeton University Press, 1985.

ERNOUT, A. Salluste, Histoires IV, 40. Revue de Philologie, 49.1, p. 57-9, 1925.

ERSKINE, A. Making sense of the Romans: Polybius and the Greek perspective. Dialogues d'bistoire ancienne, Supplément 9 (Le point de vue de l'autre), p. 115-29, 2013.

FEENEY, D. C. Beyond Greek: the beginnings of Latin literature. Cambridge, MA; London: Harvard University Press, 2016.

FENTRESS, E. Slavers on chariots. In: DOWLER, A.; GALVIN, E. R. (eds.) Money, trade and trade routes in pre-Islamic North Africa. London: Oxford University Press, 2011, p. 65-71.

FENTRESS, E. Strangers in the city: élite communication in the Hellenistic central Mediterranean. In: PRAG, J. R. W.; CRAWLEY QUINN, J. (eds.) The Hellenistic west: rethinking the ancient Mediterranean. Cambridge: Cambridge University Press, 2013, p. 157-78.

FITZGERALD, W. Slavery and the Roman literary imagination. Cambridge: Cambridge University Press, 2000.

FLAIG, E. Weltgeschichte der Sklaverei. Munich: C. H. Beck, 2009.

FOX, A. Trajanic trees: the Dacian forest on Trajan's Column. PBSR, LXXXVII, p. 47-69, 2019. DOI: https://doi.org/10.1017S006824621800034X.

FRICKER, M. Epistemic injustice:power and the ethics of knowing. Oxford: Clarendon Press, 2007.

FUTRELL, A. Blood in the arena: the spectacle of Roman power. Austin: University of Texas Press, 1997. 
GALEANO, E. Open veins of Latin America: five centuries of the pillage of a continent. Tr. C. Belfrage. New York: Monthly Review Press, 1971.

GALLINI, C. Che cosa intendere per ellenizzazione. Problemi di metodo. Dialoghi di arqueologia, 7, p. 175-91, 1973.

GARCÍA-ALIX, A.; JIMENEZ-ESPEJO, F. J.; LOZANO, J. A.; JIMÉNEZ-MORENO, G.; MARTINEZ-RUIZ, F.; GARCÍA SANJUÁN, L.; ARANDA JIMÉNEZ, G.; GARCÍA ALFONSO, E.; RUIZ-PUERTAS, G.; ANDERSON, R. S. Anthropogenic impact and lead pollution throughout the Holocene in southern Iberia. Science of the Total Environment, 449, p. 451-60, 2013.

GELLER, M. J. The last wedge. Zeitschrift für Assyrologie und Vorderasiastische Archäologie, 87.1, p. 43-95, 1997.

GOSNER, L. Extraction and empire: multi-scalar approaches to Roman mining communities and industrial landscapes in southwest Iberia. Archaeological Review from Cambridge, 31.2, p. 125-43, 2016.

HARRISON, T. Classical Greek ethnography and the slave trade. Classical Antiquity, 38.1, p. 36-57, 2019.

HARTMAN, S. Venus in two acts. Small Axe, 26.12.2, p. 1-14, 2008.

HARTMANN, B. Schreiben im Dienste des Staates. Prolegomena zu einer Kulturgeschichte der römischen scribae. In: KOLB, A. (ed.) Literacy in ancient everyday life. Berlin; Boston: Walter de Gruyter, 2018, p. 351-60.

HÄUSSLER, R. A landscape of resistance? Cults and sacred landscapes in western Cisalpine Gaul. In: CRESCI MARRONE, G. (ed.) Trans Padum... usque ad Alpes. Roma tra il Po e le Alpi: dalla romanizzazione alla romanità. Rome: Quasar, 2015, p. 261-78.

HERSHENZON, D. The captive sea: slavery, communication, and commerce in early modern Spain and the Mediterranean. Philadelphia: University of Pennsylvania Press, 2018.

HIRT, A. M. Imperial mines and quarries in the Roman world: organizational aspects, 27 BC - AD 235. Oxford: Oxford University Press, 2010.

HONG, S.; CANDELONE, J. -P.; PATTERSON, C. C.; BOUTRON, C. F. Greenland ice evidence of hemispheric lead pollution two millennia ago by Greek and Roman civilizations. Science, v. 265, n. 5180, p. 1841-43, 1994.

HOWGEGO, C. The monetization of temperate Europe. JRS, 103, p. 16-45, 2013.

HUGHES, J. D. Europe as consumer of exotic biodiversity: Greek and Roman times. Landscape Research, 28.1, p. 21-31, 2003.

HUGHES, J. D. Environmental problems of the Greeks and Romans: ecology in the ancient Mediterranean. Second edition. Baltimore: John Hopkins University Press, 2014. 
IBN SAID, O. A Muslim American slave: the life of Omar Ibn Said. Tr. A. Alryyes. Madison: University of Wisconsin Press, [1831] 2011.

INGERSOLL, K. A. Waves of knowing: a seascape epistemology. Durham: Duke University Press, 2016.

JEFFERSON, E. Problems and audience in Cato's Origines. In: ROSELAAR, S. T. (ed.) Processes of integration and identity formation in the Roman Republic. Leiden and Boston: Brill, 2012, p. 311-26.

JEWELL, E. (Re)moving the masses: colonisation as domestic displacement in the Roman Republic. Humanities, 8.66, p. 1-41, 2019. DoI: https://doi.org/10.3390/h8020066.

JIMÉNEZ, A. Changing to remain the same: the southern Iberian Peninsula between the third and the first centuries BC. In: MOORE, T.; ARMADA, X.-L. (eds.) Atlantic Europe in the first millennium BC. Oxford: Oxford University Press, 2011, p. 506-18.

JOHNSTON, A. Nostri and 'The Other(s).' In: GRILLO, L.; KREBS, C. B. (eds.) The Cambridge companion to the writings of Julius Caesar. Cambridge: Cambridge University Press, 2017a, p. 81-94.

JOHNSTON, A. The sons of Remus: identity in Roman Gaul and Spain. Cambridge, MA: Harvard University Press, 2017b.

JONES-LEWIS, M. Tribal identity in the Roman world: the case of the Psylloi. In: FUTO KENNEDY, R.; JONES-LEWIS, M. (eds.) The Routledge handbook of identity and the environment in the classical and medieval worlds. London: Routledge, 2015, p. 192-209.

KASTER, R. A. De grammaticis et rhetoribus C. Suetonius Tranquillus. Edited with a translation, introduction, and commentary. Oxford: Clarendon Press, 1995.

KAY, P. Rome's economic revolution. Oxford: Oxford University Press, 2014.

KEENAN-JONES, D. Large-scale water management projects in Roman central-southern Italy. In: HARRIS, W. V. (ed.) The ancient Mediterranean environment between science and history. Leiden and Boston: Brill, 2013, p. 233-56.

KOCH, A.; BRIERLEY, C.; MASLIN, M. M.; LEWIS, S. L. Earth system impacts of the European arrival and Great Dying in the Americas after 1492. Quaternary Science Reviews, 207, 2019, p. 13-36.

KONSTAN, D. Mass exterminations and the history of emotions: the view from classical antiquity. In: BRUDHOLM, T.; LANG, J. (eds.) Emotions and mass atrocity: philosophical and theoretical explorations. Cambridge: Cambridge University Press, 2018, p. 23-41.

LENSKI, N.; CAMERON, C. M. (eds.) What is a slave society? The practice of slavery in global perspective. Cambridge: Cambridge University Press, 2018.

LEWIS, D. M. Greek slave systems in their Eastern Mediterranean context, c. 800 - 146 BC. Oxford: Oxford University Press, 2018. 
LOZAT, M. Aux confins du monde: la Géographie de Strabon. Semitica et Classica, 12, p. $97-$ 108, 2019.

LLOYD, G. E. R. Science, folklore and ideology: studies in the life sciences in ancient Greece. Oxford: Cambridge University Press, 1983.

MACLEAN, R. Freed slaves and Roman imperial culture: social integration and the transformation of values. Cambridge: Cambridge University Press, 2018.

MACKINNON, M. Zooarchaeology: reconstructing the natural and cultural worlds from archaeological faunal remains. In: SCHEIDEL, W. (ed.) The science of Roman history: biology, climate, and the future of the past. Princeton: Princeton University Press, 2018, p. 95-122.

MARACLE, L. Memory serves: oratories. Ed. S. Kambourelli. Edmonton, Alberta: NeWest Press, 2015.

MARZANO, A. Harvesting the sea: the exploitation of marine resources in the Roman Mediterranean. Oxford: Oxford University Press, 2013.

MCCONNELL, J. R.; WILSON, A. I.; STOHL, A.; ARIENZO, M. M.; CHELLMAN, N. J.; ECKHARDT, S.; THOMPSON, E. M.; POLLARD, A. M.; STEFFENSEN, J. P. Lead pollution recorded in Greenland ice indicates European emissions tracked plagues, wars, and imperial expansion during antiquity. PNAS, 115 (22), p. 5726-31, 2018. DoI: https://doi. org/10.1073/pnas.1721818115.

MCNEILL, J. R. Europe's place in the global history of biological exchange. Landscape Research, 28.1, p. 33-39, 2003.

MEDINA, J. The epistemology of resistance: gender and racial oppression, epistemic injustice, and the social imagination. Oxford: Oxford University Press, 2013.

MEIGGS, R. Trees and timber in the ancient Mediterranean world. Oxford: Clarendon Press, 1982.

MIGNOLO, W. D. The geopolitics of knowledge and the colonial difference. South Atlantic Quarterly, 101.1, p. 57-96, 2002.

MIKESELL, M. W. "The deforestation of Mount Lebanon." Geographical Review, 59.1, p. 1-28, 1969.

MORRIS, I. Remaining invisible: the archaeology of the excluded in classical Athens. In: JOSHEL, S. R.; MURNIGHAN, S. (eds.) Women and slaves in Greco-Roman culture: differential equations. London and New York: Routledge, 1998, p. 193-220.

MYERS, M. Import/export: empire and appropriation in the Gallus Papyrus from Qasr Ibrim. In: LOAR, M. P.; MACDONALD, C. S.; PADILLA PERALTA, D. (eds.) Rome, empire of plunder: the dynamics of cultural appropriation. Cambridge: Cambridge University Press, 2017, p. 214-36.

NUTTON, V. Ancient medicine. New York: Routledge, [2004] 2013. 
OSGOOD, J. The pen and the sword: writing and conquest in Caesar's Gaul. Classical Antiquity, 28.2, p. 328-58, 2009.

PADILLA PERALTA, D. Slave religiosity in the Roman Middle Republic. CA, 36.2, p. 31769, 2017a.

PADILLA PERALTA, D. Circulation's thousand connectivities. In: LOAR, M. P.; MACDONALD, C. S.; PADILLA PERALTA, D. (eds.) Rome, empire of plunder: the dynamics of cultural appropriation. Cambridge: Cambridge University Press, 2017b, p. 261-70.

PADILLA PERALTA, D. Ecology, epistemology, and divination in Cicero De Divinatione 1.90-94. Arethusa, 51.3, p. 237-67, 2018.

PADILLA PERALTA, D. Forthcoming. Anti-race and anti-racism: the whiteness of the classical imagination. In: MCCOSKEY, D. (ed.) A cultural history of race in antiquity. London.

PADILLA PERALTA, D. In progress. Tell me how I conquered you: some clues from the second century BCE Mediterranean.

PAGDEN, A. The fall of natural man: the American Indian and the origins of comparative ethnology. Cambridge: Cambridge University Press, 1986.

PEIRANO, I. Hellenized Romans and barbarized Greeks. Reading the end of Dionysius of Halicarnassus, Antiquitates Romanae. JRS, 100, p. 32-53, 2010.

PEREGO, E.; SCOPACASA, R. The agency of the displaced? Roman expansion, environmental forces and the occupation of marginal landscapes in ancient Italy. Humanities, 7.116, p. 1-21, 2018. DOI: https://doi.org/10.3390/h7040116.

POLLARD, E. A. Pliny's Natural History and the Flavian Templum Pacis: botanical imperialism in first-century C.E. Rome. Journal of World History, 20.3, p. 309-38, 2009.

POLLOCK, S. The subject of suffering. American Anthropologist, 118.4, p. 726-41, 2016.

PRICE, S. Religious mobility in the Roman Empire. JRS, 102, p. 1-19, 2012.

PURCELL, N. The creation of provincial landscape: the Roman impact on Cisalpine Gaul. In: BLAGG, T.; MILLETT, M. (eds.) The early Roman Empire in the West. Oxford: Oxbow, 1990, p. 7-29.

PURCELL, N. Rome and the management of water: environment, culture and power. In: SALMON, J.; SHIPLEY, G. (eds.) Human landscapes in classical antiquity. London and New York: Routledge, 1996, p.180-212.

PURCELL, N. The ordo scribarum: a study in the loss of memory. MEFRA, 113.2, p. 633-74, 2001.

PURCELL, N. The way we used to eat: diet, community, and history at Rome. AJP, 124.3, p. 329-58, 2003. 
PURCELL, N. Mountain margins: power, resources and environmental inequality in antiquity. In: DERRON, P. (ed.) Économie et inégalité. Ressources, échanges, et pouvoir dans l'antiquité Classique. Vandoeuvres: Fondation Hardt pour l'étude de l'antiquité Classique, 2017, p. 75-114.

QUESADA-SANZ, F. Genocide and mass murder in Second Iron Age Europe. In: CARMICHAEL, C.; MAGUIRE, R. C. (eds.) The Routledge history of genocide. London: Routledge, 2015, p. 9-22.

RABASA, J. Tell me the story of how I conquered you: elsewheres and ethnosuicide in the colonial Mesoamerican world. Austin: University of Texas Press, 2011.

REAY, B. Agriculture, writing, and Cato's aristocratic self-fashioning. Classical Antiquity, 24.2, p. 331-61, 2005.

RIBERA I LACOMBA, A.; CALVO GALVEZ, M. La primera evidencia arqueológica de la destrucción de Valentia por Pompeyo. JRA, 8, p. 19-40, 1995.

RICHARDSON, J. S. The Romans in Spain. Oxford: Wiley-Blackwell, 1996.

RICHLIN, A. Talking to slaves in the Plautine audience. CA, 33.1, p. 174-226, 2014.

RICHLIN, A. Slave-woman drag. In: DUTSCH, D.; JAMES, S. L.; KONSTAN, D. (eds.) Women in Roman Republican drama. Madison WI/London: University of Wisconsin Press, 2015, p. 37-67.

RICHLIN, A. The traffic in shtick. In: LOAR, M. P.; MACDONALD, C. S.; PADILLA PERALTA, D. (eds.) Rome, empire of plunder: the dynamics of cultural appropriation. Cambridge: Cambridge University Press, 2017, p. 169-93.

RICHLIN, A. Slave theater in the Roman Republic: Plautus and popular comedy. Cambridge: Cambridge University Press, 2018.

RIGGSBY, A. M. Caesar in Gaul and Rome: war in words. Austin: University of Texas Press, 2006.

ROLLER, D. W. A historical and topographical guide to the Geography of Strabo. Cambridge: Cambridge University Press, 2018.

ROSELAAR, S. T. Italy's economic revolution: integration and economy in Republican Italy. Oxford: Oxford University Press, 2019.

ROYMANS, N. Conquest, mass violence and ethnic stereotyping: investigating Caesar's actions in the Germanic frontier zone. JRA, 32, p. 439-58, 2019.

RUSSELL, B. Stone use and the economy: demand, distribution, and the state. In: WILSON, A.; BOWMAN, A. (eds.) Trade, commerce, and the state in the Roman world. Oxford: Oxford University Press, 2018, p. 237-68.

SALLARES, R. Ecology. In: SCHEIDEL, W.; MORRIS, I.; SALLER, R. (eds.) The Cambridge economic history of the Greco-Roman world. Cambridge; New York: Cambridge University Press, 2008, p. 15-47. 
SANTOS, B. de Sousa. Epistemologies of the South: justice against epistemicide. Boulder: Routledge, 2014.

SANTOS, B. de Sousa. Epistemologies of the South and the future. From the European South, 1, p. 17-29, 2016.

SANTOS, B. de Sousa. The end of the cognitive empire: the coming of age of epistemologies of the South. Durham: Duke University Press, 2018.

SCHEID, J. (ed.) Römische Fragen: ein virtueller Spażergang im Herzen des alten Rom. Plutarch. Darmstadt: WBG, 2012.

SCHEIDEL, W. Quantifying the sources of slaves in the early Roman Empire. JRS, 87, p. 156-69, 1997.

SCHEIDEL, W. Human mobility in Roman Italy, I: the free population. JRS, 94, p. 1-26, 2004.

SCHEIDEL, W. Human mobility in Roman Italy, II: the slave population. JRS, 95, p. 64-79, 2005.

SCHEIDEL, W. The Roman slave supply. In: BRADLEY, K.; CARTLEDGE, P. (eds.) The Cambridge world history of slavery, Vol. 1: The ancient Mediterranean world. Cambridge: Cambridge University Press, 2011, p. 287-310.

SCHEIDEL, W. Escape from Rome: the failure of empire and the road to prosperity. Princeton: Princeton University Press, 2019.

SHANNON-HENDERSON, K. E. Religion and memory in Tacitus' Annals. Oxford: Oxford University Press, 2019.

SHELTON, J.-A. Spectacles of animal abuse. In: CAMPBELL, G. L. (ed.) The Oxford handbook of animals in classical thought and life. Oxford: Oxford University Press, 2014, p. 461-77.

SEHLMEYER, M. Die apuanischen Ligurer bei Livius. Geschichte einer (fast) vergessenen Deportation. Hermes, 146.4, p. 470-83, 2018.

SIMÓN CORNAGO, I. Lenguas vernáculas de Hispania escritas en alfabeto latino. Un episodio particular de la latinización. Athenaeum, 107.1, p. 55-93, 2019.

STRASBURGER, H. Poseidonios on problems of the Roman Empire. JRS, 55.1-2, p. 40-53, 1965.

TERRENATO, N. The early Roman expansion into Italy: elite negotiation and family agendas. Cambridge: Cambridge University Press, 2019.

TROUILLOT, M.-R. Silencing the past: power and the production of history. Boston: Beacon, 1995.

VAN WEES, H. Genocide in the ancient world. In: BLOXHAM, D.; MOSES, A. D. (eds.) The Oxford handbook of genocide studies. Oxford: Oxford University Press, 2010, p. 239-57. 
VEAL, R. The politics and economics of ancient forests: timber and fuel as levers of GrecoRoman control. In: DERRON, P. (ed.) Économie et inégalité: ressources, échanges et pouvoir dans l'antiquité classique. Vandoeuvres: Fondation Hardt pour l'étude de l'antiquité Classique, 2017, p. 317-57.

VOLKMANN, H. Die Massenversklavungen der Einwohner eroberter Städte in der hellenistisch-römischen Zeit. Stuttgart: Franz Steiner, 1990.

WALLACE-HADRILL, A. Rome's cultural revolution. Cambridge: Cambridge University Press, 2008.

WELWEI, K. -W. Sub corona vendere: Quellenkritische Studien zu Kriegsgefangenschaft und Sklaverei in Rom bis zum Ende des Hannibalkrieges. Stuttgart: Franz Steiner, 2000.

WESTINGTON, M. M. Atrocities in Roman warfare to 133 BC. Chicago, Illinois: University of Chicago, 1933.

WHITMARSH, T. How to write anti-Roman history. In: ALLEN, D.; CHRISTESEN, P.; MILLETT, P. (eds.) How to do things with history: new approaches to ancient Greece. Oxford: Oxford University Press, 2018, p. 365-89.

WHITT, L. Science, colonialism, and indigenous peoples: the cultural politics of law and knowledge. Cambridge: Cambridge University Press, 2009.

WILSON, A. Raw materials and energy. In: SCHEIDEL, W. (ed.) The Cambridge companion to the Roman economy. Cambridge: Cambridge University Press, 2012, p. 133-55.

WIMPERIS, T. A. Turnus's Tota Italia: Italian solidarity and political rhetoric in Aeneid 7-12. TAPA, 150.1, p. 143-79, 2020.

WOOLF, G. Tales of the barbarians: ethnography and empire in the Roman West. Chichester: John Wiley \& Sons, 2011.

YARROW, L. M. Historiography at the end of the Republic: provincial perspectives on Roman rule. Oxford: Oxford University Press, 2006.

YUSOFF, K. A billion Black. Anthropocenes or none. Minneapolis: University of Minnesota Press, 2018.

ZIOLKOWSKI, A. “Urbs direpta, or how the Romans sacked cities.” In: RICH, J.; SHIPLEY, G. (eds.) War and society in the Roman world. London and New York: Routledge, 1993, p. 69-91. 